\title{
Native Judges into Colonial Scapegoats
}

\section{Introduction}

In the nineteenth century the Russian Empire extended its domains into the Kazakh steppe and Transoxiana. Russian legal planners and officials had to secure social order in the new territories that fell within the state's purview. Both the absorption of local bodies of law into the structure of imperial governance and the official recognition of indigenously enshrined local rights and obligations were seen as necessary "to keep the peace, in return for tribute and taxes." The Russian Empire thus established a pluralistic legal regime. It introduced courts (military and civil) presided over by Russian justices and native courts presided over by qā with a view to preserving $\operatorname{sharí}^{-} a$ - or at least what Russians thought $\operatorname{sharí}^{-1} a$ amounted to before the conquest. Some features of Islamic legal culture were profoundly transformed, while others remained intact. This chapter looks at one such rupture. It shows that the legal structure of the colony required that native judges ( $q \bar{a} \hat{d} \bar{\imath} \mathrm{s})$ be depicted as corrupt, even as it encouraged many false accusations against them to be filed by Muslims with the colonial administration of Russian Turkestan.

The forms of governance that the Russians adopted in the realm of law differed little from other Western instruments of domination in Asia. St. Petersburg's civilizing mission presumed an asymmetry between imperial law and the various forms of indigenous justice. Russians believed that bringing "civic-mindedness" (grazhdanstvennost') ${ }^{2}$ to the peoples of the Kazakh steppe and Transoxiana rested on the rapprochement (sblizhenie) ${ }^{3}$ between an inferior body of law locally in use, "custom" (obychai), and the empire's

1 J. Burbank, "An Imperial Rights Regime: Law and Citizenship in the Russian Empire." Kritika 7/3 (2006): 402.

2 V. Martin, Law and Custom in the Steppe: The Kazakhs of the Middle Horde and Russian Colonialism (Richmond, uk: Curzon, 2001): 4, 43; see also P. Werth, "Changing Conceptions of Difference, Assimilation, and Faith in the Volga-Kama Region, 1740-1870." In Russian Empire: Space, People, Power, 1700-1930, ed. J. Burbank, M. von Hagen, and A. Remnev (Bloomington: Indiana University Press, 2007): 170, 184-5.

3 On the concept of sblizhenie, see Chapter 1, fn. 101. 
superior legal system, "the law" (zakon). In their view, this transformation of local practices could be achieved without using force to introduce imperial law. Russian authorities thus allowed colonial subjects to present cases before local legists in "native courts" (narodnye sudy), but they hoped, with time, to impress upon them the greater desirability of operating within the imperial legal system. ${ }^{4}$

The institutional arrangements that were established in Central Asia, however, differed significantly from the solutions that had been applied in other Muslim-majority regions of the empire. In 1788 Catherine the Great established the Muslim Spiritual Administration, in the form of a muftiate in the Ural town of Ufa, to supervise the local mosque communities of European Russia, as well as to appoint and control their imams; another task of the muftis was to issue fatwas and regulations that would legitimize state policy and legislation from an Islamic point of view. It is usually held that Islamic law became confined, in daily practice, largely to issues of personal status, that is, registering births, marriages, and divorce and dealing with issues of inheritance. ${ }^{5}$ These were the fields that the tsarist administration left largely to the imams of the local mosque communities. Other important aspects of Islamic law, however, such as charitable endowments (waqfs) to finance mosques and schools, were, in the VolgaUrals, often left in a gray area, without official recognition. In the region under the purview of the muftiate, Muslims could, and did, bring their affairs to "communes" (Russ. zemstvo, pl. zemstva) and jury trials, at least after Alexander II's (r. 1855-81) reforms of the judiciary. This was not the case in Russian Central Asia, where communes did not exist and judicial powers were, instead, in the hands of the military. ${ }^{6}$ As we shall see, when Muslims appealed to the Russian government, their grievances were actually heard by military officers who deliberated with wide discretion on points of law specific to sharita. It is thus common to find officers seconded to Turkestan who had not been initiated into the rudiments of Islamic law and who deliberated creatively on waqf law, property rights, customary dowry, the law of evidence, and so forth. This situation had serious unintended consequences for the practice of law in general, and, more specifically, for the legal culture of the colony. Military officers most often resolved conflicts by applying both imperial law and Islamic law, thereby

4 E. Schuyler, Notes of a Journey in Russian Turkestan, Khokand, Bukhara, and Kuldja, 5 th ed., 2 vols. (London: Sampson Low, Marston, Searle, and Rivingston, 1876): 1:168.

5 R.D. Crews, "Empire and the Confessional State: Islam and Religious Politics in NineteenthCentury Russia." AHR 108/1 (2003): 76 fn. 94.

6 A.S. Morrison, "Metropole, Colony, and Imperial Citizenship in the Russian Empire." Kritika 13/2 (2012): 329 . 
hybridizing procedures in forms that are typical of colonial situations. Central Asia represents, from this point of view, an exception in which the rule of law, as imagined by legal planners in the imperial metropole, was suspended. Such an arrangement made the region institutionally different from those areas under the rule of the Muslim Spiritual Administration.

Although the watchword among Russian lawmakers was "preservation" (sokhranenie), ${ }^{7}$ the formal incorporation of local customs into the body of the imperial law in fact brought about new legal cultures. Imperial legal taxonomies distinguished between laws for settled communities of Muslims and laws for nomads. Such a distinction reflected a widespread assumption that the nomads were only superficially Islamized: "the Kazakhs are Muslim only in name" (musul'manin Kirgiz-musul'manin tol'ko nominal'nyi), noted one colonial officer. ${ }^{8}$ In the eyes of the Russians, the legal culture of the nomads made a case for absolute indigeneity. Kazakhs were thus regarded as subjects of a legal order called adat (Ar. 'ädat), which was deemed less articulate than Islamic law proper:

The main difference between shari'a and 'a $\overline{d a t}$, that is the legal system according to the native customs of the Kazakhs, is that sharía distinguishes criminal from civil offenses. 'A $\bar{A} d a t$, does not, however, conceive of penal offenses and includes the latter without any distinctions in the category of civil misdemeanors, which are sanctioned with material compensations for the offended party or her kinfolk. ${ }^{9}$

The colonizers not only disambiguated customary law from sharîa on the basis of procedural differences. They also conceived of laws as mirroring the varying nature of the peoples inhabiting the region. Russians thus held that the Kazakhs qua nomads followed a legal system different from sharita because they were naturally unsuitable for a normative order based on Islam. From the Russian point of view, sharīa courts simply could not exist (sushchestvovat'ne mozhet) among the Kazakhs, ${ }^{10}$ whose law "was based on customs that are harmless for the people and for the government, while the legal system of the $q \bar{a}$ dīs is based on the laws of Muhammad (Magomet), develops fanaticism, and places the people in a restricted space that does not permit intellectual

7 Ob ustroistve sudebnoi chastiv Turkestanskom krae, chap. 3, Ustroistvo suda, 1881, TsGARUz, f. I-1, op. 27 , d. 68, l. 1.

8 Ibid.: 1. 14ob.

$9 \quad$ Ibid.: 1. 3 .

10 Ibid.: l. 1ob. 
growth."11 Consequently, in the Hobbesian world of Russian planners and officials, members of settled communities would have to refer to native courts presided over by qā resolve their conflicts before a native judge called, in Russian, biy (Chaghatay, $b \grave{\imath})$ who was said to apply customary law.

Given that the term $b \bar{\imath}$ appears repeatedly in this study, it is worth clarifying its historical meaning and its evolution after the Russian conquest of Central Asia. Numerous contemporary Russian observers stated that bīs had traditionally filled a voluntary office and that their authority to arbitrate in disputes had been contingent upon the consent of both opposing legal parties. ${ }^{12}$ In contrast to this view, outside the Governorship-General of Turkestan, bis' legal authority reflected their powers as tribal leaders, which were conferred upon them by the local ruler. ${ }^{13}$

To begin to grasp how sharīa and 'ädat became essential components of a state-sponsored regime of legal pluralism, let us imagine a single day in a town somewhere in colonial Central Asia. A certain Būra Bāy appears before an Islamic judge in pursuit of redress. He has initiated legal action against a certain Mullā Bāy, whom he accuses of stealing his horse. After the qā dì has

\footnotetext{
11 Ibid.: 1l. 3-3ob.

12 "Although the term biy is most often translated as judge, it is wrong to associate the position with a formal court of law, such as one would find in the reform-era legal system in Russia proper. That is, traditionally, the biy owed his title neither to formal training, nor to appointment to a post. Rather, he accepted the honor of being called a biy by virtue of his knowledge of Kazakh 'ädat and of his ability to mediate a situation fairly. In general, a biy was any person to whom disputants turned to help them resolve disputes." Martin, Law and Custom in the Steppe: 27. The same view can be found in R.D. Crews, For Prophet and Tsar: Islam and Empire in Russia and Central Asia (Cambridge, MA: Harvard University Press, 2006): 216 "Kazakhs assume the title biy on an informal basis."

13 See the diplomas for the appointment of bis among the Qaraqalpaqs under the rule of the Qunghrats, which were published in Dokumenty arkhiva khivinskikh khanov po istorii i étnografii karakalpakov, ed. Iu. Ė. Bregel' (Moscow: Nauka, 1967): 297-98, 431, 530. On the appointment of bis among the Kazakhs (qazaqīya ùlūs) in the Dasht-i Qipchaq, see Muhammad Bahādur Khān's diploma in favor of Shāh Murād b. Sārī Qul, who was appointed to govern the Mehdiqulī branch (tìra) of the 'Ālim clan (khalq) in 1856, TsGARUz, f. I-125, op. 2, d. 14, l. 1. For other examples, see TsGARUz, f. I-125, op. 2, d. 12, l. 1; d. 9, l. 1. Although among the Kyrgyz of the Tian Shan, the title $b i$ was acquired by succession, it clearly had an imperial dimension, as appointments to office required the issuance of diplomas by Qing agencies. See D.G. Prior, "High Rank and Power among the Northern Kirghiz: Terms and Their Problems, 1845-1864." In Explorations in the Social History of Modern Central Asia (19th-2oth Century), ed. P. Sartori (Leiden: Brill, 2013): $142-3$.
} 
ruled in his favor, ${ }^{14}$ Būra Bāy leaves the judicial chamber and walks past a man named Tura Bāy, who is about to enter a courtroom applying Kazakh customary law. Tūra Bāy's son was murdered by members of his clan (urügh) a few days earlier. At first, it seemed that the murder would result in retaliation, but influential individuals successfully mediated between the parties, persuading Türa Bāy to relinquish his claim in return for a consideration. ${ }^{15}$ While the contract of amicable settlement is being recorded, a certain Sayyid Ghazīkhān is in the office of Georgii Lamzdorf, a Russian notary. Ghazikhān intends to circumvent the application of the Islamic law of inheritance. He wants to secure, according to Russian personal-status law, the legal entitlements of his daughters, who, according to shari $a$, would be entitled to receive only a smaller share. Lamzdorf solemnizes Ghazikhān's will, which stipulates that, on his death, his estate is to be divided equally among his heirs. ${ }^{16}$ The notary stays on late in his office, and it is dark when he finally manages to put away his papers and leave the building. On his way out, he hears angry shouting from a neighboring courtyard, where Khāl Muhammad and his associates have just broken into the house of Tūlaghān Āy, Khāl Muḥammad's divorced wife, and a quarrel over marital obligations is coming to blows. The next morning, assisted by her son, Tūlaghān Ây will file charges of assault and battery against her former husband in the Russian imperial court. ${ }^{17}$

This is a bricolage of judicial records of several legal proceedings at different times and in different places in Russian Central Asia. In connecting these stories, I have attempted to illustrate how events analogous to these could have occurred simultaneously in many cities in the region: the documentation produced by the Russian civil-military administration leaves little doubt of this. The cases I have pieced together from various records might, with a little latitude, be seen as a snapshot of a routine day in an urban Central Asian courtroom during the period of Russian rule: an urban Muslim notable obtaining a ruling from the judge of a native court applying sharîa; a case involving Kazakhs in the room next door being determined according to customary law; and a variety of other indigenous legal protagonists requesting that their cases be heard under Russian civil and penal law.

14 Sharīa court register (Beshagach district, Tashkent), entry no. 3, 25.04.1882, TsGARUz, f. I-36, op. 1, d. 2170, l. 2.

15 Certificate of amicable settlement (șulh) produced by Kazakh arbitrators (bïlär) in Tashkent, 07.07.1868, TsGARUz, f. I-36, op. 1, d. 434, l. 11. I translated it and commented on it in "The Birth of a Custom: Nomads, Sharĩa Courts and Established Practices in the Tashkent Province, ca. 1868-1919." ILS 18/3-4 (2011): 304-305.

16 TsGARUz, f. I-365, op. 1, d. 94, ll. 2-3ob.

17 TsGARUz, f. I-21, op. 1, d. 59. 
Nothing in the examples I provide departs substantially from what had been envisaged by Russian planners. The statutory laws (polozhenie) applied in Central Asia specified that indigenous city dwellers and nomads should apply their own "custom"-Islamic law or customary law, respectively-and could also, if they wished, bring cases in the Russian imperial courts or take their grievances directly to the colonial administration.

Imagined between St. Petersburg and Tashkent, this was the legal order of an empire's colony into which new paradigms of legality were to be introduced. The legal system was designed to draw the indigenous population closer to the sphere of influence of imperial law and encourage Central Asians to adopt new, more "civilized" patterns of conduct. In this respect, the Russians were pursuing an ambitious project of cultural engineering, one element of which sought to transform the ways their colonial subjects could seek and achieve legal redress. Underlying this project lay an unquestioned faith in the cultural superiority of imperial law to local customs, well articulated in the words of Virginia Martin: "in order to effect change and promote progress [...] toward abidance by the rule of law (zakonnost'), Russian officials would rule their subjects by example, with 'benevolent guidance' not force or imposition."18

Russians no doubt regarded native courts as temporary institutions ${ }^{19}$ that would soon be replaced by imperial judicial institutions called "justices of the peace" (mirovoi sud). The colonial legal project was based on the idea that local legal cultures would one day give way to new ideas of civic mindedness and that the cultural diversity between the colonizers and their subjects would be eliminated in favor of the introduction of the rule of law: "[native courts] can be tolerated under certain restrictions only. Leaving this system in place [...] will bring about a decrease of its importance, while our legal system will conquer the trust of the people." ${ }^{20}$ The introduction of imperial law was, however, constantly deferred..$^{21}$ Several governors-general and other officials did attempt to do away with the native courts but, as happened in other colonial judicial settings, such projects were not brought to fruition. By retaining the native courts until the last days of the empire, the Russians never came close to achieving that universalizing governmentality to which they had long aspired. ${ }^{22}$ Far from achieving universality, they reinforced difference. This does not mean, however, that the Russians failed to extend imperial law among the Muslim communities of Central Asia. Contrary to the view that only rarely

\footnotetext{
18 Martin, Law and Custom in the Steppe: 36.

19 Crews, For Prophet and Tsar: 268.

20 TsGARUz, f. I-1, op. 27, d. 68, ll. 3-3ob.

21 Crews, For Prophet and Tsar: 292.

22 J.L. Comaroff, Colonialism, Culture, and the Law: A Foreword." LSI 26 (2011): 306-7.
} 
did Central Asians bring their grievances before the justices of peace, ${ }^{23}$ locals often did ask that their cases be heard according to Russian law. ${ }^{24}$ Admittedly, this generally happened in unusual situations in which Muslims found themselves unable to negotiate their grievances within the Muslim community and had to appeal to an alternative court. Muslims most probably brought far fewer legal actions before imperial forums than they did before the native courts. Regardless of the frequency of such actions, however, appeals by Muslims to the colonial administration reveal the force of the imperial episteme, reinforcing, as they did, the logic behind the civilizing mission of the Russian Empire.

In adopting, as I do, the imperial term "native court" (narodnyi sud), I want to suggest that we are dealing with an institution designed for the colony and, consequently, with an institutional innovation. This is not to suggest, of course, that the Russians invented the office of $q \bar{a} d \bar{\imath}$ nor that they made up Islamic law. Even a cursory comparison of the notarial output of $q \bar{a} d \bar{i}$ s before and after the establishment of Russian rule allows us to appreciate the persistence of many formulaic expressions. Continuities in the formulaic character of Islamic notarial output reflect the degree to which qā $\mathfrak{l i s}^{\prime}$ legalese was a conservative language that remained stable throughout the centuries ${ }^{25}$ and was scarcely susceptible to adaptations. If, however, one had to read the social history of the native courts from the point of view of their notary activity, one would misidentify the changes that occurred in the practice of Islamic law. By embedding sharīa in the colonial institutional edifice, Russians necessarily changed many of the attributes of Central Asian Islamic judicature. In the eyes of the colonizers, a $q \bar{a}$ dì was now a "native judge" (narodnyi sud'ia), that is, a local official who served the empire and, as such, could receive rewards for his labor and was entitled to a retirement pension. ${ }^{26}$ Central Asians, by contrast, regarded $q \bar{a}$ dīs as the guarantors of Islamic law in Russian Turkestan but did not find in them the same men who had represented the traditional legal regime that operated under the khans' rule. Continuities with the past were observable more in theory than in practice. The courts presided over by qā once were accountable directly to the royal courts and to governors and which were regularly visited by bailiffs and mediators, became under Russian rule, "qā

23 Crews, For Prophet and Tsar: 261.

24 See Chapter 4.

25 Ol'ga Chekhovich wrote a magnum opus on this subject, which remains unpublished. See her Istoriia razvitiia aktov iuridicheskogo oformleniia feodal'nykh otnoshenii v Srednei Azii XII-XVI vv. (written in Tashkent 1979), unpublished manuscript, TsGARUz, f. R-2678, op. 1, d. 60 . 
Needless to say, qādīs were now operating in a juridical field that was substantively different from the one in which they used to live and which I outlined in Chapter 1.

In this chapter, I will show that the establishment of native courts entailed both advantages and disadvantages for local legists. I shall do so by eavesdropping on the life of a Tashkent "native judge," Muhyī al-Dīn Khwāja. A man of distinguished juristic pedigree-his father, Muhammad Ḥakīm Khwāja Îshān, had served as chief judge (qū Khoqand-Muhyī al-Dīn Khwāja was one of the most prominent personalities, not only in the colonial juridical field but also in the wider public space of colonial Tashkent. His Russian-language obituary, by the famous Orientalist Nikolai Ostroumov, ${ }^{27}$ leaves little doubt about the importance of the role that Muhyī al-Dīn Khwāja played as cultural broker (posrednikom mezhdu etoi vlast'iu $i$ narodom) at the heart of the Governorship-General. Ostroumov's recollections about Muhyī al-Dīn Khwāja are almost exclusively enthusiastic, praising the Muslim legist for implementing the new laws of the empire and his exemplary conduct that persuaded others to come closer ( $k$ sblizheniiu) to the Russians. Ostroumov knew many things about Muhyī al-Dīn Khwāja, especially his dealings with imperial officials. Not only does Ostroumov tell how Muhyī al-Dīn Khwāja attended events of great significance both in the metropole and the colony and describe his two decorations with the orders of St. Stanislav and St. Anna: he also recounts how Muhyī al-Dīn Khwāja was somehow "spoiled" (izbalovanny) by the exceptional degree of attention that Russian officials, including many generals and military governors, accorded him. Despite his defective knowledge of Russian, the Muslim legist became an insider also in the sometimes hostile spheres of the imperial bureaucracy.

If Ostroumov's obituary opens a window on a few important aspects of Muhyī al-Dīn Khwāja's world, his apparel, and lifestyle-including a "special room" (osobaia komnata) that he had fashioned in the style of a Russian house in order to welcome European guests - it also suppresses many other facets of his personality. The repeated elections to the position of narodnyi sud'ia offered Muhyī al-Dīn Khwāja many chances to accrue wealth as a landowner in both the city and the garden belt outside the walls of Tashkent. At his death, he left an impressive paper trail that documents his various transactions designed to increase his wealth in land and cash. Most of his properties followed the

27 Reprinted in N.P. Ostroumov, Sarty. Étnograficheskie materialy (obshchii ocherk), 3rd ed. (Tashkent: Tip. Gazety “Sredneaziatskaia Zhizn," 1908): 125-31. 


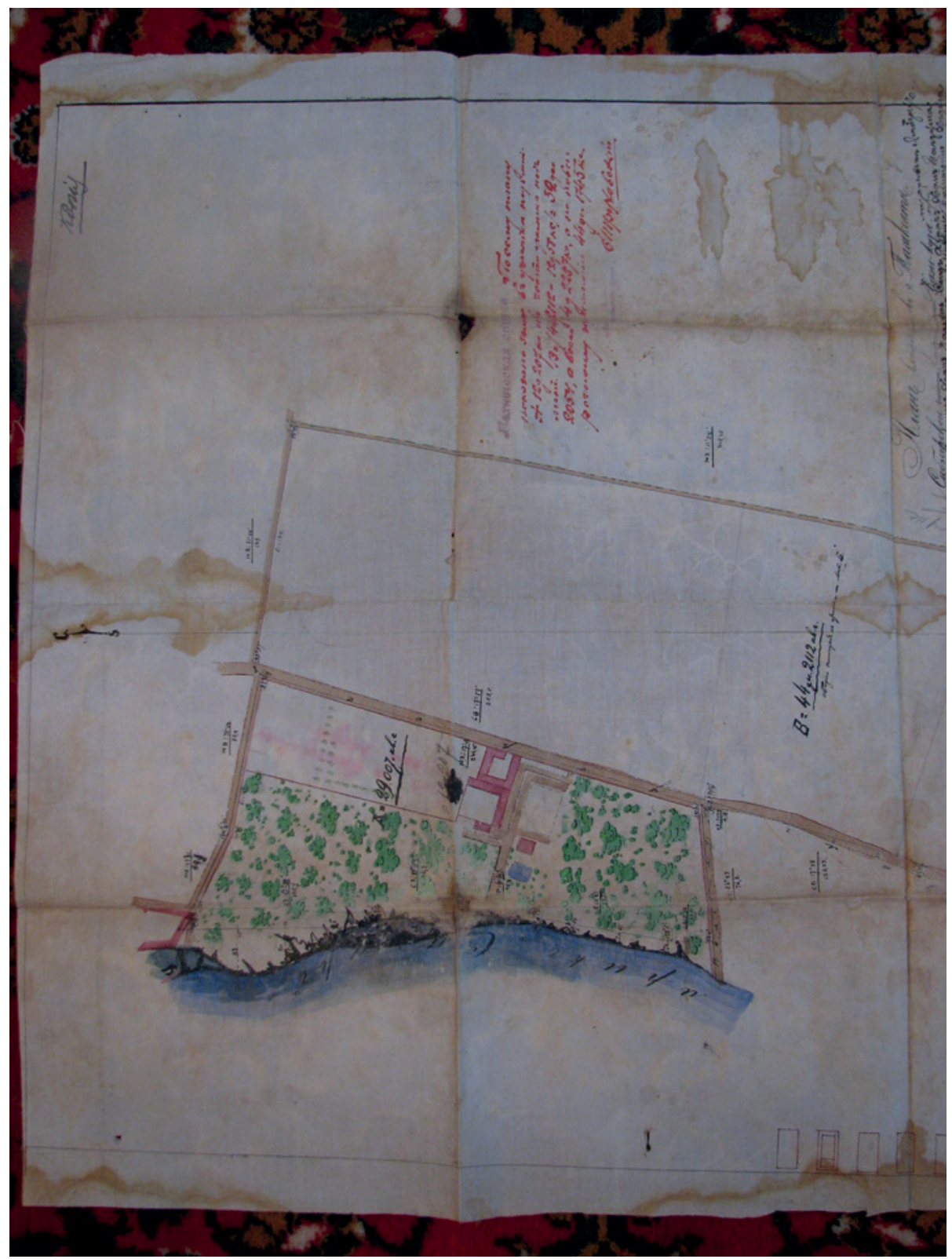

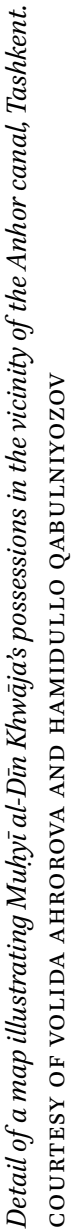

숭 
rules of devolution of the Islamic law of inheritance, the traces of which we today find scattered in the Central State Archive of Uzbekistan and the private collections of the offspring of his niece, Vosila Ahrorova. ${ }^{28}$

By serving the empire as a $q \bar{a} d \bar{l}$, he also often acted in the capacity of guardian for underage children, having at his disposal large amounts of cash that allowed him to operate somewhat freely as a money lender. ${ }^{29}$ His role as gobetween is also important for the character of Muhyī al-Dīn Khwāja. As we shall see in Chapter 5 , his juristic output, especially that which he produced in conversation with Russian officials, combined Islamic writing traditions, such as fatwas and juristic tracts, with extended reflections on Russian statutory laws and bureaucratic practices.

As his patrimony and influence grew, however, so did the number of his enemies among both the locals and Russian officials. Tashkentis repeatedly accused him of bribery, judicial malpractice, and abuse of power. Imperial bureaucrats spied on him and concocted stratagems to remove him from office. He had to step down only once, in the wake of the 1892 "cholera riot," which has beautifully reconstructed Jeff Sahadeo. ${ }^{30}$ The figure of Muhyī al-Dīn Khwāja is both exceptional and exemplary of the biographies of many other native judges, who could exploit bureaucratic and political resources to amass considerable wealth; ${ }^{31}$ who enjoyed unprecedented leeway in levying fines and other sanctions; ${ }^{32}$ and who ultimately were subjected to increased criticism with respect to both their morality and their skills as legists.

28 Vosila Ahrorova (b. 10.01.1926) is the daughter of Muhyī al-Dīn Khwāja's youngest son, Sayyid Ahrār Khān. The latter must have inherited most of the codices and lithographs that constituted Muhyī al-Dīn Khwāja's private library, while his deeds probably went to his other two sons. The Central State Archive of Uzbekistan acquired a significant number of such deeds in 1939 from a certain Zafar Alimov. See the introduction to the description, called Tashkentskii Kazi Kalian, of the two inventories (opisi) that describe the collection I-164.

29 I have discussed this in "Constructing Colonial Legality in Russian Central Asia: On Guardianship." cssh 56/2 (2014): 419-47.

30 J. Sahadeo, Russian Colonial Society in Tashkent, 1863-1923 (Bloomington: Indiana University Press: 2007): 94-107, esp. 104-5.

31 G.A. Arendarenko, Dosugi v Turkestane, 1874-1889 (St. Petersburg: Tipografia M.M. Stasiulevich, 1889): 169 .

32 Otchet po revizii Turkestanskogo kraia po Vysochaishemu poveleniiu Senatorom Gofmeisterom Grafom K.K. Palenom. Narodnye Sudy Turkestanskogo Kraia. This is noted in Crews, For Prophet and Tsar: 268. 
The incorporation of local bodies of law into the legal system of the empire was designed in accordance with imperial legal planners' notion of "reform." Reforma was the key word used by Russian officers and administrators when they drew up regulations to make the application of Central Asian law more efficient and to make sure that the legal practice of local communities complied with imperial standards. ${ }^{33}$ From the following discussion, however, it will be clear that such reform amounted to redrawing the scope of the jurisdiction of the qā formation. But such transformation was less proclaimed than subtly labored during the endless back-and-forth between the offices of the colonial administration. The changes of day-to-day notarial and judicial practice in Islamic law did not respond only to the will of Russian legal planners.

The establishment of Russian rule in Central Asia coincided with the drafting of the Provisional Statute (Proekt Polozheniia), a set of temporary regulations issued in July 1867. It was, however, the 1886 Statute $^{34}$ (partially amended in 1901) that provided colonial authorities with guidelines for regulating the life of local peoples. With regard to the practice of law, the major difference between the 1867 and the 1886 statutory laws consisted in the latter's replacement of imperial tribunals, once exclusively staffed by the military, with justices of the peace. It took at least two decades to separate the judicial from the administrative powers. Predictably, many administrative-military personnel did not like such a rearrangement, which endowed Russians officials and Muslim subjects with the same legal standing in a public court. ${ }^{35}$ Despite resistance from parts of the colonial elite, beginning in 1886 justices of the peace in Turkestan began work. In the absence of the communes, however, the justices serving in these courts were not elected by the local communities but were appointed directly by the ministry. ${ }^{36}$

The 1886 statute $(\S 117)$ stated that there were, in general, three instances of justice in Russian Turkestan: the justice of the peace, who operated at

33 N. Frideriks, “Turkestan i ego reform.” Vestnik Evropy 6 (1869): 691-712.

34 Polozhenie ob upravlenii Turkestanskogo kraia. (2 iiunia $1886 \mathrm{~g}$ ). In Materialy po istorii politicheskogo stroia Kazakhstana (so vremeni prisoedineniia Kazakhstana k Rossii do Velikoi Oktiabr'skoi sotsialisticheskoi revoliutsii). ed. M.G. Masevich (Alma-Ata: Izdatel'stvo Akademii Nauk Kazakhskoi ssR, 1960): 1:352-79.

35 N. Mordvinov, Zapiska k proektu o sudebnoi reforme v Turkestanskom krae, 1891, TsGARUz, f. I-18, op. 1, d. 139, ll. 2-5ob.

36 J. Baberowski, "Law, the Judicial System, and the Legal Profession." In The Cambridge History of Russia, vol. 2, Imperial Russia, 1689-917, ed. Dominic Lieven (Cambridge: Cambridge University Press, 2006): $35^{8}$. 
the district (uezd) level, a court in each province (oblast'), and the senate (senat).${ }^{37}$ These institutions had jurisdiction over the entire population of the Governorship-General of Turkestan (§ 140). They ruled on crimes perpetrated against the government, the Orthodox Church, the fiscal system, and the public (for example, deceit, treason, incitement of opposition to the government, damage to telegraph lines, murder, usurpation, and robbery) (§ 141), and they had jurisdiction over every kind of crime or tort perpetrated by a native against a Russian $(\S 142)$. In addition to these courts presided over by Russian officials, there were native courts, which acted "on the basis of existing customs" (na osnovanii sushchestvuiushchikh [...] obychaev) (§ 208), where "custom" was a notion broad enough to include sharía. These courts could hear only cases in which the parties came from the indigenous population. In the native courts, legal proceedings were conducted in accordance with either Islamic or tribal customary law. A court was chaired by a single judge operating within a clearly delimited territorial jurisdiction. This was not an innovation, as territoriality had long been a characteristic of the office of $q \bar{a} d \bar{l}^{3}{ }^{38}$ What was new, however, was the notion that "the jurisdiction of civil actions is determined by the place of residence of the defendant, while for penal cases it is defined by the place in which the crime has been perpetrated" ( $§ 212)$, that is, what is often referred to in legal language as actor sequitur forum rei. ${ }^{39} \mathrm{~A}$ consultative judicial body (Russ., s"ezd) with several judges represented a tribunal of appeal whose decisions were definitive ( $(240)$. In addition, the colonial rulers introduced norms that interfered with local legal systems: 1 ) if both parties agreed, Muslims could bring a case to a justice of the peace or to an oblast' court ( $(213) ; 2$ ) by lodging a complaint in the chancery of the district commandant, a Muslim could appeal a decision of a people's court ( $§ 243$ ). These regulations were drafted to enable the colonial government to become directly involved in administering justice over its subaltern subjects but might also disrupt the extension of the rule of law to the colony: though statutory laws hinged on a separation of powers many conflicts were, as we shall see, resolved directly by having the military

37 In Russian Turkestan, a uezd denoted a district with a population of 250,000 or more; an oblast' was a province ruled by a governor and having a population of up to one million; cf. Morrison, Russian Rule in Samarkand, 1868-1910: A Comparison with British India: xxiv.

38 My opinion here differs from Crews, For Prophet and Tsar: 268, and from Morrison, Russian Rule in Samarkand, 1868-1910: A Comparison with British India: 249, who relies on L. Kostenko, Sredniaia Aziia i vodvorenie v nei Russkoi Grazdhanstvennosti (St. Petersburg: V. Beozobrazov, 1870): 63-64.

39 The article was not amended in the 1901 Statute but was rubricated as article 214; see Polozhenie ob upravlenii Turkestanskogo kraia s izmenieniiami i dopolneniiami po 1-e ianvaria $1901 \mathrm{~g}$. (Tashkent: Tip. Porcevykh, 1901). 
man the key offices in the administration of the Governorship-General on the basis of their own extrajudicial considerations. Such regulations were often conducive to authoritarianism, especially when military officers ruled on cases at their own discretion. This situation resembles what the Italian philosopher Giorgio Agamben terms a "state of exception,"40 that is to say, a suspension of judicial authority that strengthens the executive powers of the state and leaves its subjects to face the disciplinarian whims of law.

The most noteworthy reform introduced by the Russians in Central Asia in the realm of indigenous law during nearly five decades of rule involved the method of appointment to the office of judge. The colonial government decided that native judges would be elected every three years. The system was not based on direct voting: instead, ballots were cast only by representatives of fifty households (called ïllikkbāshì) in the communities in every defined area of settlement, such as a city district or a village. To become effective, the results of elections had to be confirmed by the colonial authorities. This applied to settled communities electing their qā dīs. In the same way, nomads were to elect the judges (bis) for 'ädat-based courts.

In general, the colonial government attempted to limit the jurisdiction of $q \bar{a}$ dịs to cases of personal status, succession, and charitable endowments. Native judges, however, informally retained authority over criminal offenses such as usurpation of land, ${ }^{41}$ assault, rape, and robbery, despite the criminal offences falling officially under the jurisdiction of the justices of the peace. ${ }^{42}$ They also introduce a sanction-oriented provisions in order to replace the hudüd system, that is, a set of fixed punishments for offenses that are considered under Islamic law to be "violations of the claims of God (huqūq Alläh)"43 and over the application of which the judge has no discretion. The basic guidelines for the reorganization of the judiciary in Central Asia under the umbrella of Russian rule are to be found in the judicial reform signed by Alexander II in 1864, which called for avoiding arbitrariness, allowing oral argumentations, and holding public trials. More specifically, Russian administrators sought to introduce immediately into the Central Asian legal environment the idea that

40 G. Agamben, State of Exception, trans. K. Attell (Chicago: University of Chicago Press, 2005).

Zhurnal soveta Turkestanskogo General-Gubernatora, 22.11.1891, TsGARUz, f. I-717, op. 1, d. 6, ll. $495^{-512 .}$

42 Martin, Law and Custom: 92. See, e.g., the following cases of animal theft in the Sībzār $q \bar{a} d \bar{c}$-court register for the year 1899: TsGARUz, f. I-365, op. 1, d. 74, 1l. 45, 77, 83, 117, 149, 155 . R. Peters, Crime and Punishment in Islamic Law: Theory and Practice from the
the Twenty-First Century (Cambridge: Cambridge University Press, 2005): 7 . 
judges should be independent, being elected by the members of their community.4 This marked an epochal change: under the rule of the khans, judges and anyone else providing legal services used to be appointed directly by the royal court. An observer contemporary with the Russian reforms noted that the introduction of elections to the native judge's office, the establishment of judicial assemblies as tribunals of second instance, ${ }^{45}$ and the abolition of corporal punishments ultimately shattered the previous $q \bar{a} d \underline{\imath}$ courts (sobstvenno govoria, sovershenno unichtozhil prezhnii kaziiskii sud). ${ }^{46}$

What the colonizers termed "judicial reforms" amounted, then, more to the restriction of the jurisdiction of the native courts than a complete refashioning of legal tradition. The Russians in Central Asia never pursued this more ambitious latter goal, framing their juridical reforms instead in that larger strategy of noninterference (ignorirovanie) that sought to avoid stirring up local feelings of discontent. "To exert violence upon the people is to ignite that spark that will light a fire," ${ }^{n 7}$ declared an official supporting the idea that criminal offenses such as animal theft and murder should be left in the purview of 'adat courts. We could call this a pragmatic solution. Understaffed as it was, the colonial government in Turkestan would not, in any case, have had the means to introduce the rule of law by force. But there was more. The colonizers believed that, in the long run, introducing new legal practices and integrating them with existing ones would lead the local population to lose respect for their

44 Baberowski, “Law, the Judicial System, and the Legal Profession” 344-68.

45 Russian officers often claimed that consultative judicial bodies (§ 240) were an institution that already existed in precolonial Central Asia. One of the most eloquent advocates of this view was the state counsellor (deistvitel'nii statskii sovetnik) Ivan Ivanovich Kraft (1861-1914). In his work on the legal system in Russian Turkestan, he held that "[people] who were dissatisfied by the rulings of the $q \bar{a}$ di $\bar{i}$ appealed to the governor upon whose order cases were transferred to consultative judicial bodies" (ne dovolnye resheniiami kaziev prinosili appeliatsii beku, po rasporiazheniiu kotorogo dela peredevalis' na reshenie s"ezda kaziev); cf. I.I. Kraft, Sudebnaia chast'v Turkestanskom krae i v stepnykh oblastiakh (Orenburg: Tipo litografiia N.N. Zharinova, 1898): 61. This was plainly false. Just a few decades after the publication of Kraft's work, the Soviet Orientalist Aleksander A. Semenov explained that the local judicial system did not include appellation or cassation; see his Ocherk ustroistva tsentral'nogo administrativnogo upravleniia Bukharskogo khanstva pozdneishego vremeni (Stalinabad: Izdatel'stvo Akademii Nauk Tadzhikskoi SSR: 1954): 31-2.

46 Otchet po revizii Turkestanskogo kraia po Vysochaishemu poveleniiu Senatorom Gofmeisterom Grafom K.K. Palenom. Narodnye Sudy Turkestanskogo Kraia (St. Petersburg: Senatskaia Tipografiia, 1909): 8.

TsGARUz, f. I-1, op. 27, d. 68, l. 15 . 
mores and choose the purportedly more civilized imperial tribunals. ${ }^{48}$ This belief was based on the idea that the native judges' corruption (podkupnost') would inevitably undermine the credibility of sharita to the advantage of the imperial tribunals..$^{49}$ Establishing native courts was thus seen as a temporary concession to the local subjects to gain their trust.

Measuring the extent of the reordering of the indigenous legal systems is important not only for discerning the motives of the legal reforms but also for recognizing their unintended consequences. Judicial reforms, though important and substantive, stopped at the threshold of procedural law. Finegrained Russian-language treatises devoted to the mechanics of Islamic law were conspicuous by their absence. After decades of experience in Central Asia, lawmakers' intentional avoidance of engaging with $q \bar{a} d \bar{c} \bar{s}$ ' hearings suggests a particular vision of colonial intervention in the realm of indigenous law. Russians' plans of legal reforms apparently did not envisage codification. Codification was a performative representation of cultural domination as well as a successful tool for transforming Islamic law from a jurists' law into a statutory law. Statutory law consisted of a clear set of rules, a code, that we see applied in other Muslim-majority regions under colonial rule and that, in general, helped to make sharī $a$ a consistent and predictable legal system. ${ }^{50}$ With the sole exception of the attempt made by Count Pahlen at the beginning of the twentieth century, the codification of shari $a$ was long disregarded as an instrument of rule in Russian Turkestan..$^{51}$

2 Elections

Electing their own judges (and tax officials) was, for Muslims in Central Asia, a break with the past. ${ }^{52}$ In precolonial times the centralized administration of

48 G. Zagriazhskii, "O narodnom sude u kochevago naseleniia Turkestanskago kraia, po obychnomu pravu (zan')." In Materialy dlia statistiki Turkestanskago kraia, ed. N.A. Maeva (St. Petersburg: Tip. Transhelia, 1876): 4:19o; Kraft, Sudebnaia chast'v Turkestanskom krae i v stepnykh oblastiakh: 92.

49 TsGARUz, f. I-1, op. 27, d. 68, l. 3ob, 4.

5o A. Layish, "The Transformation of the Sharīa from Jurists' Law to Statutory Law in the Contemporary Muslim World." WDI 44/1 (2004): 85-113.

51 A. Morrison, "Creating a Colonial Shari'a for Russian Turkestan: Count Pahlen, the Hidaya and the Anglo-Muhammadan Law." In Imperial Cooperation and Transfer, 1870-1930: Empires and Encounters, ed. V. Barth and R. Cvetkovski (London: Bloomsbury, 2015): 127-49.

$5^{2}$ Otchet po revizii Turkestanskogo kraia po Vysochaishemu poveleniiu Senatorom Gofmeisterom Grafom K.K. Palenom. Narodnye Sudy Turkestanskogo Kraia: 8. 
the khanates had appointed its representatives ('amaldār), even at the village level. The appointment to a certain administrative position was conceived as a means of establishing reciprocity between the state and its representatives, based on an exchange of favors: if an administrator proved loyal to the state, he would enjoy certain benefits, the most common being tax exemption. ${ }^{53}$ This meant that, behind an appointment made by the local ruler or representatives of the state, there were often factions lobbying for an official administrative position. As an endorsement from a local governor usually involved fiscal privileges, these benefits were probably redistributed among the group who supported a candidature. ${ }^{54}$ We have seen the ritualized repertoire of conferral of appointments to judicial offices in the Bukharan emirate and in Khorezm. The situation was similar in Tashkent under Khoqandi rule, where diplomas of appointment to the position of $q \bar{a}$ d $\bar{\imath}$ were issued up to the eve of the Russian conquest. ${ }^{55}$ Local groups lobbied to have their members appointed directly to some judicial capacity until the introduction of the Provisional Statute in $1867 \cdot^{56}$

Introducing the electoral process for the appointment of native judges among the Muslim population marked a first important event that would test the strength of the Russian government. At the beginning of 1868 , a special commission was given the task of explaining to the locals the main traits of the Provisional Statute. ${ }^{57}$ The commission that was created to mediate

R.N. Nabiev, Iz istorii kokandskogo khanstva (Feodal'noe kkhoziaistvo Khudoiar-Khana) (Tashkent: Fan, 1973): 242 and passim. Such fiscal privileges could be bestowed as a tarkhān status granting immunity mainly "to religious figures such as prominent Sufis or members of sacred lineages," W. Wood, A Collection of Tarkhan Yarliqs from the Khanate of Khiva. Papers on Inner Asia 38 (Bloomington: Indiana University Research Institute for Inner Asian Studies, 2005): 29-30. This is true also for other regions of precolonial Central Asia, such as the Ferghana Valley; cf. A. Juvonmardiev, XVI-XIX asrlarda Farghonada ersuv masalalariga doir (Tashkent: Fan, 1965): docs. 18/42, 105/71, 6/81. A state appointment to an official post did not, ipso facto, imply the privileges described.

54 A. Wilde, "Creating the Façade of a Despotic State: On Āqsaqāls in Late 19th-Century Bukhara." In Explorations in the Social History of Modern Central Asia (19th-Early 2oth Centuries), ed. P. Sartori (Leiden: Brill, 2013): 267-98.

55 Copy of a diploma for the appointment of Abū al-Khayr Khwāja Zāhir to the office of qā for the city of Turkestan and the Kazakh tribal groups (ïlāt) of the province, March-April 1865, TsGARUz, f. I-336, op. 1, d. 14, ll. 129-30.

$5^{6}$ Nazar Khwāja Shaykh al-Islām to Cherniaev, with a request to appoint a certain Mullā 'Abd al-Ṣamad Qāḍī to office, n.d., TsGARUz, f. I-336, op. 1, d. 14, l. 128; see another petition of local residents and notables to appoint Mullā 'Umar Qāọī, n.d., TsGARUz, f. I-336, op. 1, d. 14, l. 1310b.

57 F. Azadaev, Tashkent vo vtoroi polovine XIX veka. Ocherki sotsial'no-ekonomicheskoi $i$ politicheskoi istorii (Tashkent: Izdatel'stvo Akademii Nauk Uzbekskoi ssR, 1959): 96. 
between the Russians and the local population on issues pertaining to elections included Tashkenti 'ulamä’ such as Hakīm Khwāja, who had served as qā 'Azīzlār Khwāja, and other notables such as the merchants Sayyid 'Aż̄im Bāy and 'Azīm Āqsaqāl. Needing to implement institutional changes, the Russians obviously relied on the local elite, which included a learned hierarchy (mullahs and makhdhüms) and individuals claiming the status of the descendants of saints (sayyids, khwäjas). But the distinguished titles attached to personal names leave little doubt that the commission consisted chiefly of the old

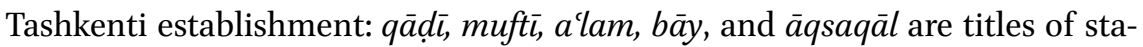
tus attached to the names of the members of the commission and reminiscent of older power relations. They also chart a space of moral authority that the Russians had yet to invade. ${ }^{58}$ The colonial masters soon became aware of the challenges posed by the constituency on which they relied. Besides indulging in the usual Orientalist tropes in characterizing their local interlocutors-for example, "apathetic" (apatichnym i vialym) and "underdeveloped" (po nerazvitosti svoei) —Russians noted how difficult it would be to break the older bonds of reciprocity and unfold all instances of machination against them. They also sensed that the members of the commission were, as go-betweens, less concerned with the commission's proclaimed goals than with the necessity of pleasing colonial officials and the 'ulam $\bar{a}^{2} .{ }^{59}$ Reviewing the following passage ${ }^{60}$ from the records of the 1868 electoral commission will help us appreciate the complicated nature of what the Russians sought to achieve:

The chairman [of the commission] asked whether they [members of the commission] know what [the ballots] are collected for, what the elections are, and what depends on them. The population should know that they do not have to hesitate to elect whom they want; the administration hopes that good people will be elected. The populace must keep in mind that, under the former governments, it was the rulers who appointed [judicial] officials who did not care about the people, oppressed [the locals], extorted illegal fees, and abused their power. The current government, on the contrary, cares about its subjects and deems it necessary that officials be elected by the people and approved by the people's superiors, for people know better who are the good individuals and who can

$5^{8}$ See the charts of local representatives of the Tashkent city district, TsGARUz, f. I-1, op. 16, d. 66 , ll. 12-13.

59 Ibid.: $1.65 \mathrm{ob}$.

6o Ibid.: 1. 36 . 
be useful. Elections for these positions will take place every three years, and the people cannot change [elected] officials before their three-year term is up. If they find anything [wrong about such appointees], let them bring a complaint to the commandant of Tashkent. As they listened to all the things the chairman had to say, the members [of the commission] answered that they understood everything. They thanked the authorities for their care and expressed the belief that good people would be chosen, given that the elections would affect their own well-being. The chairman then explained the electoral procedure. Everyone entitled to elect [a native judge] should write the name of one candidate on a note and drop it in a box. Those who are illiterate should apply to Ibragimov, one of the translators. When all select a name and drop their ballots into the poll, the box will be opened in the presence of all the electors: he who receives the most votes will be elected to the post.

When the commission touched on the issue of the election of the native judges, it was objected by a Tashkent clique that the electoral procedure contravened shari ${ }^{i} a$. The commission responded to this objection in a way that would later become standard for collaborations among the colonizers and the 'ulam $\bar{a}$. They tried to find a solution from within the Islamic juristic tradition and requested a fatwa to answer the following questions: could Muslims, where the ruler is not a Muslim, still perform their prayers on Friday and during major festivities? And could they appoint a qā $\bar{l}^{2} ?^{61}$ In response to these questions, the jurists concluded that Muslims can join in assembly (jamā'a) and reach an agreement (ittifāq) to appoint to the office of judge (qū in Islamic law. Formulating this opinion amounted to little more than glossing in Persian and Chaghatay what could be found in such established collections of legal opinions as the thirteenth-century Fuṣul al-Imād $\bar{\imath}^{62}$ and the fifteenth-

61 TsGARUz, f. I-1, op. 16, d. 66, ll. 7-6. Text unstamped.

62 This is a work also known as Fuṣūl al-ị̣kām fì uṣūl al-aḥkām, compiled in Samarkand by 'Imād al-Dīn Abu al-Fatḥ 'Abd al-Rahīm Zayn al-Dīn b. Abū Bakr al-Samarqandī (d. ca. 1271). See $G A L$ SI: 382 (656). It was a text widely used by Muslim jurists in Central Asia and is quoted extensively in the opinions issued by the jurists and in the lists of books left by local scholars; cf. Isāmīi-yi kitābhā-yi mawjūda ba dast-i faqür az manqūlāt-i bahr al-manäfiq, Ms Samarkand, Library of the Historical Museum of Samarkand, 4089/9, fol. 3 r. The list bears the seal of Mullā Abū al-Qāsim Muftī, which is dated 1322/1904-5; see also N.P. Ostroumov, Islamovedenie. Shariat po shkole (mazkhab) Abu-Khanify (Tashkent: Tip. Pri Kants. Turk. Gen.-Gub: 1912): 17; A. Idrisov, A. Muminov, and M. Szuppe, Manuscrits en écriture arabe du Musée regional de Nukus (République autonome du Karakalpakstan, 
century Jāmi' al-fatāw $\bar{a} .{ }^{63}$ The colonial innovation of the elections had, in this way, survived the permissibility test of Islamic law. ${ }^{64}$ It was neither an attempt to comply with Islamic "orthodoxy" nor a pretext to draw new boundaries around the attributes of the $q \bar{a} d \bar{\imath}$. Soliciting this fatwa was simply a way for the commission to rebut objections to the innovation of the elections.

The introduction of the new regulation reflected a pragmatic approach to the deregulation of judicial authority. In the early 1860 s, the colonizers did not know much about Central Asia and feared the traditional patronage system of the khans. They therefore hoped that the locals would, if granted the right to vote, choose the most respectable person among their peers (bolee pochitaemoe (itso), a person whose moral virtues would also guarantee that he would be skilled in administrative work. Colonial officers could thus avoid, they thought, the risk of choosing the wrong person, as this was no longer their responsibility. ${ }^{65}$ Russians, however, retained the power to confirm the results of the elections. In this way, they had, in principle, the last say on every elected candidate. In some cases, the Russians certainly used such power to appoint to office jurists who, they thought, would best serve their interests. Here is one such case:

\author{
Commandant of Tashkent \\ to the Military Governor of Syr-Darya Province \\ April 8-9 1874
}

\title{
Report
}

According to the regulations of your Excellency dated 22 September 1873 no. 6904, I have organized the election of $q \bar{a} d \bar{l}$ s [...] for the next triennium. Consequently, I have the honor to request the approval of $[\ldots]$ the individuals elected to the aforesaid positions, whose names I here enclose. In this case, I consider it necessary to report that I thought to confirm 'Aẓim Khān in the post of qā dị in the Besh-Agach district, even though [he received] fewer votes. He has already served two to three years [in the same capacity] and has proved himself capable of continuing this activity not only in a way that does not cause any harm to our

Ouzbékistan). Fonds arabe, persan, turkī et karakalpak (Rome: Istituto per l'Oriente C.A. Nallino, 2007): 82.

63 A work by Qirq Emre al-Ḥamīdī al-Ḥanafī (d. 1475), see GAL SII: 226 (316).

64 TsGARUz, f. I-1, op. 16, d. 66, l. 3 .

65 Ershov, "Neskol'ko slov o vyborakh." TV 75 (1908): 105. In 1885, the commandant of the Perovsk District noted that the natives should blame themselves (vina samogo naroda) for their inability to elect skillful candidates, TsGaRUz, f. I-17, op. 1, d. 4082, l. 19. 
interests but also, in some cases, in a manner that is very helpful to us. Meanwhile, the majority of the inhabitants of the Besh-Agach [district], whose population consists of ishāns [Șūfì masters], has voted for 'AzịmKhwāja Īshān, who, like all ishānns, is among the most bigoted servants of Islam. This ishān distinguishes himself from other citizens even by his clothes: he is always dressed in white, he walks without shoes, and in general represents, in the eyes of the ignorant crowd of their worshippers, some kind of saint. [...] I wish that our government would not allow such a fanatic to attain the office of $q \bar{a} d \bar{l}$. He is the one who not only fulfills the duties of a judge among the Asiatic population but who also has very often engaged in the interpretation and explanation of the rules and regulations of the shari $a$ to the population. Indeed, with the upcoming introduction of a new statute in the region, an official of so fanatical a disposition will be very harmful. Therefore I humbly beg and plead Your Excellency to approve 'Azīm Khān for the next triennium as a man already tested. ${ }^{66}$

In assessing the impact of the elections on the career of the legists, one should bear in mind that far more $q \bar{a} d \bar{l}$ s were active in Russian Turkestan than was the case under the khans: "in every hole they [the Russians] made one policeman (mingbāshì), one $q \bar{a} d \bar{l} \overline{\text {, }}$ seven trustees (amīn), and fourteen ïllikbāshìs," noted the chronicler Mīrzā 'Ālim Tāshkandī in 1884, observing how, in the district of Khoqand alone, there were now twenty judges. ${ }^{67}$ Pahlen's report indicates that, at the beginning of the twentieth century, 275 native judges were serving in Turkestan, many more jurists than were appointed as $q \bar{a} d \bar{\imath}$ before the Russian conquest. The case of Tashkent is telling: since 1868 , four native judges were elected to office, one in each city district (daha), while under the rule of Khoqand there had been periods when one qādī was enough for the entire province, including the Qurama district, located south of Tashkent and inhabited mostly by Kazakhs. ${ }^{68}$ Elections did not result in a continuous turnover

66 TsGARUz, f. I-36, op. 1, d. 883, ll. 31-32.

67 Mīrzā 'Ālim Tashkandī b. Dāmullā Mīrzā, Ansāb al-ṣalāțīn wa tảrīkh al-khawāqīn, Ms Tashkent, TsVRUz, no. 1314/I: 17ob.

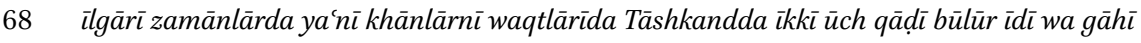

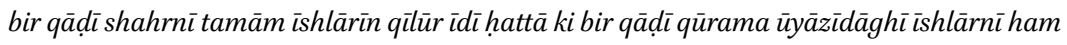
qülūr ìdī ammā Tāshkand shahrī ūrūsìya dawlatīgha tābi bülghändan sung ham bir nicha waqtlār tūrt dahagha bir qā dị būlūb tūrdī, Raḥimm Khwāja Īshān 'Alī Khwāja İshān-ūghlī ( $q \bar{a}$ ḍi of the Sibzar district) to the Tashkent city commandant, 28.10.1893, TsGARUz, f. I-36, op. 1, d. 3494, l. 4. The information provided by the native judge is confirmed by diplomas of appointment to the office of qā $\bar{d} \bar{\imath}$ for the province (wilāyat) of Tashkent under the rule of the khans of Khoqand; see Dāmullā [the rest of the name is unlegible], 1822-3, 
of legists as was the case under the rule of the khans and the emirs, nor did it lead to a great deal of instability: there were many judicial positions now to fill, and the electoral procedure was left in the hands of local actors. Positions were exchanged for money, and squabbles among local groups frequently followed elections to such posts. ${ }^{69}$ Pahlen even referred to the election system as a complete failure because of bribery cases, ${ }^{70}$ though prosecutors often found that such accusations were groundless. The colonial masters rarely overturned the outcome of judicial elections, as they were bound de jure to the will of those who voted. Nor can one discern much from the texts that voters produced to notify the colonial administration about their agreeing to the results of a particular election. Russians received a list of names with seals and signatures that looked as if it was designed to leave little room to intrude into the groups' dynamics, which led to the appointment of an individual to a post of native judge. ${ }^{71}$ Such texts were termed "election documents" (Russ., vyborny list, Uzbek, șāylāw khatț), ${ }^{72}$ but they were also termed, in local parlance, "letters of agreement" (ittifäq-nāma). Seldom do we recover in these documents the voices that could reveal the grubby details of the elections. In one such case, for example, we find that the selection of a candidate to a certain office was, in fact, a private enterprise arranged among a few individuals who later turned to the voters and asked them to draft a false "receipt" (kfitānsa, Russ., kvitantsiia). ${ }^{73}$ As the voters could hide their machinations behind the succinct wording of their lists, we can assume that Russians did not have the power to reveal the truth behind such elections. The newly introduced electoral system created an atmosphere of suspicion, and enemies, as the qā Khwāja explained:

TsGARUz, f. I-3232, op. 2, d. 81, l. 1; Īshān Maḥmūd Khwāja Zahīr, 1810 and 1847, TsGARUz, f. I-323, op. 2, d. 89, l. 1 and d. 87, l. 1; Mahmūd Khwāja Îshān, 1854, TsGARUz, f. I-323, op. 2, d. 88 , l. 1. The situation varied from place to place. Until the end of the 1870 s, Samarkand could count on just one qāậ̄; see Arendarenko, Dosugi v Turkestane: 168-9; Morrison, Russian Rule in Samarkand, 1868-1910: A Comparison with British India: 259. The situation later changed drastically as is reflected also in the sharîa-based notary output in the province of Samarkand; see T. Welsford and N. Tashev, A Catalogue of Arabic-Script Documents from the Samarqand Museum (Samarkand and Istanbul: IICAS, 2012): passim.

69 See the discussions among Russian officials following the election of 'Ādil Khwāja to the office of native judge; he had been opposed by 'Azịim Khwāja İshān supported by the influential Sayyid 'Az̄ìm Bāy, TsGARUz, f. I-36, op. 1, d. 883.

70 Otchet po revizii Turkestanskogo kraia: 11.

71 TsGARUz, f. I-164, op. 1, d. 50, l. 2.

72 TsGARUZ, f. I-36, op. 1, d. 883, l. 3 .

73 Judicial report, 31.10.1892, TsGARUz, f. I-164, op. 1, d. 50, l. 4. 
To his Majesty, the Commandant of Tashkent. Appeal of the native judge of the Sibzar district of Tashkent, Muhammad Muhyī al-Dīn Khwāja Ishanov. 5 July 1897. Muhammad Khwāja 'Abdū 'Az̄ìm Khodzhinov sued me before the native court for a sum of more than 2,00o rubles. Because I am the respondent, the lawsuit has been transferred to the $q \bar{a} d \bar{\imath}$ of the Shaykhantaur district, who, on 14 April 1898, ruled against the claim on account of a lack of evidence. The plaintiff was dissatisfied with the decision and appealed to the assembly of native judges [ $s^{\prime \prime} e z d$ narodnykh sudei]. Because of the lack of personnel [...], Your Excellency has been pleased to order the appointment of new candidates to the post of judge. $[\ldots]$ In an attempt to safeguard not only my interests but also the interests of justice, which I have served as far as [I have been able] with honor for many years, I take the liberty of submitting to your Majesty some considerations with respect to the personnel of such judicial assembly. [...] It should be taken into account that the present case is the fruit of hatred towards me and desire for revenge, not only on the part of the plaintiff but also by the whole party hostile to me. The enmity of this party [partiinaia vrazhda] generates all sorts of rumors, and I would be very uncomfortable if I were to win this case: people in the city would begin to say that the composition of the assembly reflected [my] biased attitudes towards the case, as it included one who was my supporter or successor. ${ }^{74}$

Factionalism soon became the major result of the election system introduced by the Russians. The establishment of a tribunal of second instance $\left(s^{\prime \prime} e z d\right.$ kaziev) enjoying powers of judicial review, exacerbated local antipathies even further, as illustrated by the passage I have just quoted. Factionalism among the ' ulam $\bar{a}^{\prime}$ was already widespread across Central Asia before colonization. The works of Șadr al-Dīn 'Āynī and Șadr-i Ḍiyā' illustrate the conflicts between families and groups of scholars in Bukhara and show how the Manghit rulers exploited such conflicts for their own benefit. ${ }^{75}$ They also illustrate how, in relating instances of factional rivalry, authors generally take a partisan view of events, sympathizing with one group against another. Ṣadr al-Dīn 'Āynī thus depicts Badr al-Dinn, who was appointed to the position of chief judge by the Bukharan emir 'Abd al-Ahad, as "unrivalled in despotism and without equal in

74 Muhyī al-Dīn Khwāja's appeal to the Tashkent city commandant, o6.o2.1899, TsGARUz, f. I-36, op. 1, d. 3881, l. 11.

75 Șadr al-Dīn 'Āynī, Bukhārā inqilābinning ta'rīkhī, ed. S. Shimada and S. Tosheva (Tokyo: Dept. of Islamic Area Studies, Center for Evolving Humanities, Graduate School of Humanities and Sociology, University of Tokyo, 2010): 54-57. 
power" (istibdādda bì-hamtā wa tadbīrda bì-mānand). ${ }^{76}$ Șadr-i Diyā adopts a slightly different position, emphasizing instead how factionalism was reflected in the removal from office of individuals who had earlier been appointed by the opposing factions and the cooptation, instead, of people removed from their post. From Șadr-i Ḍiyā's highly colored account, we learn that, among the first institutional innovations materializing with his tenure as chief judge, Badr al-Dīn appointed to the position of madrasa instructor persons who had earlier been dismissed from the office of $q \bar{a} d \hat{l} \bar{l}$, lacked sufficient knowledge,

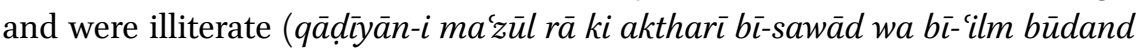
$\bar{a}$ warda mudarris sākht). ${ }^{77}$

The idiom changes significantly, however, when we turn to vernacular narratives produced during the Russian period. These works often depict elected members of the native administration so contemptuously that one wonders whether such portrayals are intended to serve some larger rhetorical purpose of critiquing colonial society. Qädīs who were elected to office under Russian rule are presented as dishonest, unqualified for judicial duties, and prone to bribery. The account offered by one of the last Khoqand chroniclers, Mīrzā 'Ālim Tāshkandī, provides a vivid illustration of such a critical disposition towards the colonial administration and its native judges. I quote here one such passage that includes a portrayal of the new qādīs and is reminiscent of the caricatures one would find in the periodical press [Fig. 8]:

They [the Russians] said that that they would elect [to the office of] $q \bar{a}$ ḍi two honest men [ba-diyannat ādam], but they did not accept for the position of judge several honest and just mullahs who were among the scholars the wealthy [of Khoqand] had selected [as candidates]. Instead, they accepted as qā who had been [previously] dismissed from office [but] who had [for the occasion] let his beard and mustache grow. Moreover, they accepted as judge also one Mullā Mīr Ma'sūm, who is the son of the [former] chief judge Dāmullā Muḥammad Yūsuf. They [the Russians] gave them a robe,

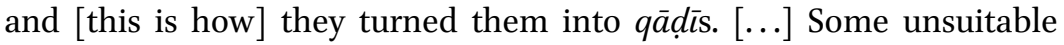
[nā-munāsib] individuals [also] bribed [pāra birīb] native administrators [amin wa illikkbāshì] with three or four hundred rubles and became qā in the village, while other, honest, individuals were marginalized. ${ }^{78}$

\footnotetext{
76 Ibid.: 54 .

77 Tarjuma-yi ậwāl-i Qāộ̄ Aabd al-Shakūr, Ms Tashkent, TsVRUz, no. 1304/IV: fol. 101b.

78 Mīrzā 'Ālim Tashkandī, Ansāb al-șalāținn wa-ta'rīkh al-khawāqīn: fol. 150a-152a. This passage has been paraphrased also by Bakhtiyar Babadzhanov in his Kokandskoe Khanstvo: Vlast', Politika, Religiia (Tokyo and Tashkent: NIHU Program Islamic Area Studies Center
} 


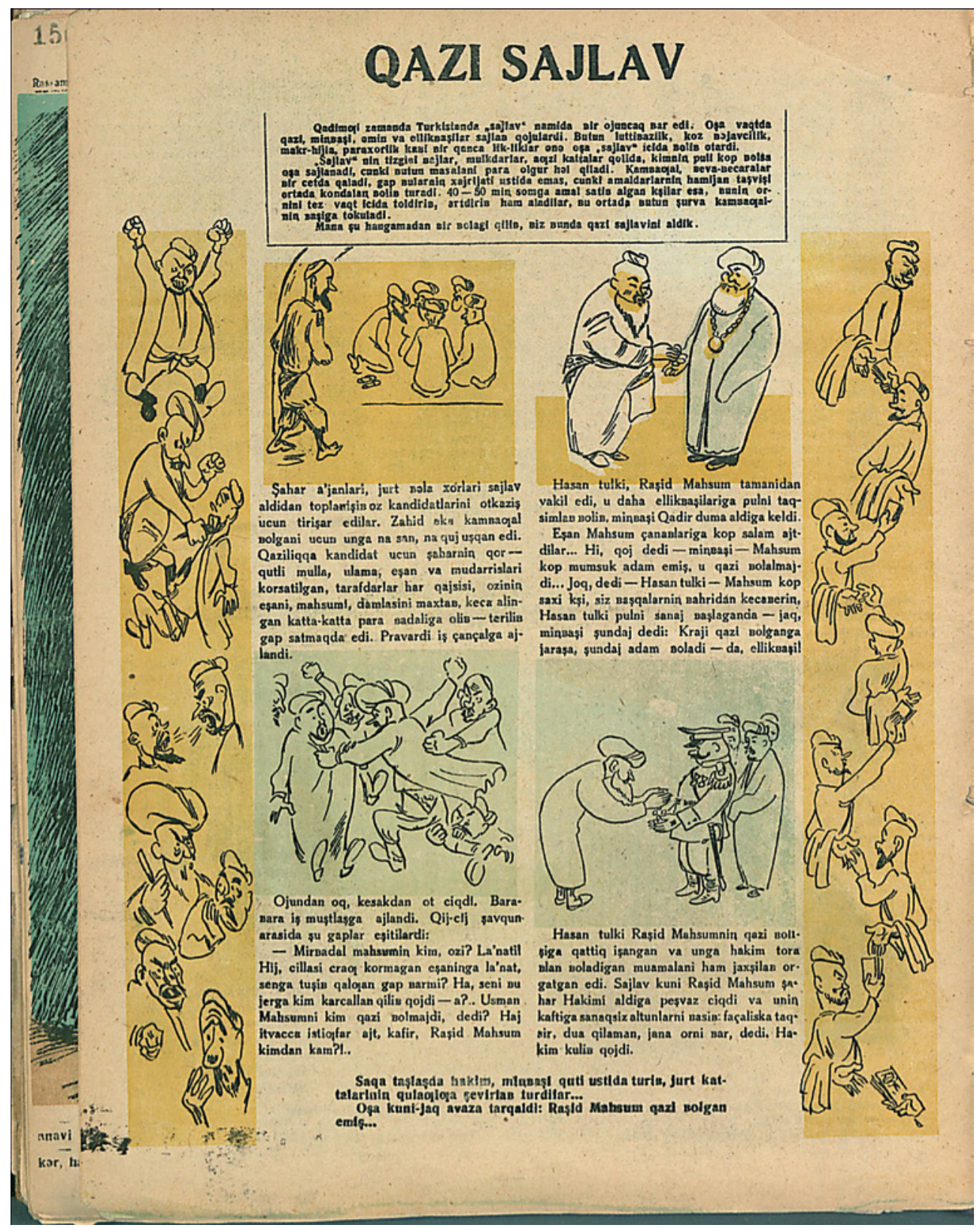

FIGURE 8 "Qādị̄s' election" under Russian rule, according to the satirical journal Mushtum, 17-18.og.1937. 
Central Asians began to see elections as a mark of moral decay. This attitude became so prevalent in local communities that it later became a topic of satirical poetry. The Khoqandi poet 'Ubaydallāh Ustā Sāliḥ-ūghlī, alias Zawqī (1853-1921) devoted a long poem of rhyming couplets (dāstān) to a famous turf war between two local legists-Mullā Kamāl and Mullā Ḥakīmjān—who contended for the post of $q \bar{a} d \bar{l}$ in one district of the city of Khoqand in 1909. The fight between the two parties involved, as usual, the Russian authorities, especially the city's commandant, Viktor Medinskii, who, in the end, sided with Mullā Hakīmjān and endorsed his election. Here is the passage from the poem containing Zawqī’s rendition of Mullā Ḥakīmjān's victory:

Medinskii the governor with his attendants / came and gathered the community.

He questioned everyone about the event / so he could see [for whom] the people agreed.

They praised Ḥakimjān by inflating [his name] / and cooked up the affair in this way.

The opinion of the governor went in favor of Hakīmjān. / He said: "The office of $q \bar{a} d \bar{\imath}$ belongs here [to this man]." ${ }^{79}$

Many believed that one elected to the office of $q \bar{a}$ di $\overline{~ m u s t ~ h a v e ~ b e e n ~ s i d i n g ~ w i t h ~}$ the Russians and must therefore be irremediably corrupt. ${ }^{80}$ This was how $q \bar{a} d \bar{l} \bar{s}$ lost their moral standing in local society.

3

\section{Judges as Scapegoats}

Rather than simply an object of public contempt, the purported inclination of native judges to bribery, malpractice, and ignorance of the law became for Central Asians a resource to use to their own benefit. I say "purported" because

at the University of Tokyo, 2010): 560-1. Babadzhanov seems to confer on Mīrzā 'Ālim Tāshkandī a positive epistemological status. The text, however, clearly suggests that the author had anti-Russian dispositions, for he claims that those locals who served the Russians were a bunch of thugs and that, under the colonial government, immoral behavior such as prostitution and murder became prominent (fol. 151b).

79 Gh.K. Karimov, O'zbek adabiioti tarikhi. Uchinchi kitob (XIX asrning iqqinchi iarmidan XX asr boshlarigacha) (Tashkent: O'qituvchi, 1975): 210.

8o See the poems of the Uzbek Zavqi $\left(1853^{-1921)}\right.$ at http://zerrspiegel.orientphil.uni-halle .de/t599.html and http://zerrspiegel.orientphil.uni-halle.de/t585.html. 
colonial officials, from their first appearance in the region, proclaimed their concern for the moral attributes of native judges. ${ }^{81}$ This concern, whether sincere or not, was a cornerstone of the colonial project to replace native judges with imperial tribunals. The important aspect of such cases is not really the attempt of Central Asians to involve colonial authorities in mediating disputes. ${ }^{82}$ This happened in the case of Russian statutory laws, and the administrative setting of the Governorship-General openly invited the colonial subjects to appeal to tsarist officials. As we have seen in Chapter 1, this was hardly an innovation, as it was customary among locals to turn to their rulers for redress. What invites reflection is instead the ability of colonial subjects to adjust their language of grievance to the idiom of colonial bureaucracy. Such an ability not only shows how receptive and responsive was the local population to new cultural patterns and changing social circumstances but also reflects a process of "legality," the culture of law and the sense of legal entitlement that people possessed as individuals or as members of a community. Fundamental to Central Asian Muslims' sense of legality during the period of Russian rule was the idea that the native judges had to be portrayed before the colonial masters as corrupt. There are too many accusations of bribery and embezzlement leveled against $q \bar{q} d \bar{c} \bar{s}$, inspired by malice, to support the view that native courts in Russian Turkestan were a colonial showcase of "undoubted corruption." ${ }^{83}$ I do not mean to exclude the possibility that native judges were corrupt. Bribery is a topic as old as the Muslim world, ${ }^{84}$ and native judges operating in Russian Central Asia are no exception. ${ }^{85}$ In addition, their judicial duties make

81 See, e.g., I.F. Kostenko, Sredniaia Aziia i vodvorenie v nei Russkoi Grazhdanstvennosti (St. Petersburg.: Tip. B. Bezobrazov, 1871): 64; N. Dingel'shtedt, "Odno iz otzhivaiushchikh uchrezhdenii." ZGUP 7 (1892): 1-23; A. Zuev, "Kirgizskii narodnyi sud." Zhurnal ministerstva iustitsii 12 (1907): 161-208. Many sources also demonstrate that the Russians viewed the $q \bar{a} d \underline{c} \bar{s}$ with suspicion and were disturbed by their moral authority over the local communities; see, e.g., TsGARUz, f. I-21, op. 1, d.s 75, 108, 113, 114, 144, 202.

82 Crews, For Prophet and Tsar, 268: Morrison, Russian Rule in Samarkand, 1868-1910: A Comparison with British India: 259.

83 Ibid.: 284 .

84 M. van Berkel, "Embezzlement and Reimbursement. Disciplining Officials in 'Abbasid Baghdad (8th-10th Centuries AD)." International Journal of Public Administration 34 (2011): 712-19.

85 In his memoirs, Mīr Sayyid Muhyī al-Dīn b. Mīr Sayyid Ḥabīballāh Fatḥābādī recounts a case in which a qā guilty of machinations (buhtān) in a case of extortion. See his Khātirāt, Ms Tashkent, TsVRUz, no. 328/IV, fols. 113-114 (second half the nineteenth century). 
qadīs particularly liable to public criticism and satire, ${ }^{86}$ especially because they could deploy power that many did not have: "if your claimant is a judge, [you'd better] express your grief to God," says an Uzbek proverb. ${ }^{87}$

Taking accusations of corruption at face value, however, is problematic for various reasons. First, qadīs' "bribery" (rishwa) was a key term of the idiom of hatred that, before the Russian conquest, Muslims used to express disapproval of their conduct as legists and blacken their name. In his Khuläsat al-ậwāl (1886), ${ }^{88}$ the Tashkent savant Abū 'Ubaydallāh refers to a dispute between his father and a "stranger" (bìgāna wa bìrūna) over a plot of garden land abutting the courtyard where his family lived. His father had a particular interest in the property in question, because his courtyard was, by all accounts, too small for the family, but the stranger was able to purchase the property first. When the father of Abū 'Ubaydallāh heard this, he protested before the legists of Tashkent, claiming that his right of pre-emption (shuf'a), as owner of property abutting the plot under question, had been overridden. But the legists dismissed the protest, because the purchaser had bribed them to do so (chizhà ba-țaríqa-yi rishwa dāda). ${ }^{89}$ In 1828 , eleven muftis from Tashkent opined on a case in which a person who had lost a case subsequently insulted the adjudicating qā $\bar{d} \bar{\imath}$ by calling him "corrupt" (rishwa khwur). The jurists held that, according to Islamic law, the slanderer should be liable to punishment (mustahaqq-i ta'zir) and explained that it was incumbent upon the qä his denouncer an exemplary punishment (tazirir-i baligh). ${ }^{90}$ These examples would suggest that accusations of corruption reflect instances of bribery less than the accusers' antipathy toward the $q \bar{a} d \bar{\imath} \mathrm{s}$.

A second problem with taking accusations of corruption at face value is that it obscures the significance of a longstanding culture of gifts (hadya) and donations (tārtīq), which were regarded as marks of respect, loyalty, and

86 I have in mind here the satirical poem of Sidqii Khondailiqii (1884-1934) against the $q \bar{a}$ ḍi of O'n Qo'rghon, whom he called ignorant (nodon) and corrupt (rishva desa tashlab o'zini tomdin). See his Tanlangan asarlar, ed. B. Qosimov and R. Javharova (Tashkent: Ma"naviiat, 1998): 211-13.

87 Da"vogarning qozi bo'lsa, dardining olloga ait, B. Sarimsoqov et al., O'zbek khalq maqollari (Tashkent: Fan, 1978): 190.

88 T.K. Beisembiev, Annotated Indices to the Kokand Chronicles (Tokyo: Research Institute for Languages and Cultures of Asia and Africa, 2008): 22.

89 Abū 'Ubaydallāh Khwāja Tāshkandī, Khulāṣat al-aḥwāl, ms Tashkent, TsVRUz, no. 2084: fol. 5 a.

Anon., Jung, Ms Tashkent, TsVRUz, no. 6102: fol. 321b. 
submission in politics ${ }^{91}$ and law.92 In Chapter 1 we saw how the judge Barāq Khwāja strongly opposed the custom current among Turkmens from Kerki of presenting gifts to the judges. The qad $\vec{\imath}$ s attitude, as it was recounted by his son, may seem perfectly logical to us. Evidently, however, the governor in Kerki regarded the practice as perfectly legitimate, and, in deciding whether the practice was right or wrong, the historian risks falling prey to his or her own unstated moral beliefs. What may seem to certain jurists perfectly normal - the payment for the bailiff's service, say, or the charging of a notary's fee-may appear to others as deplorable..$^{93}$ It is possible that the culture of gift exchange survived the conquest and the institutional reorganization of the judicial system. If so, our approach should not be informed by the fact that some contemporary observers regarded such cultural practices as forms of corruption and depravity. These reporters may well have been acute commentators, but they were perhaps not fully attuned to Central Asian culture. The American consul in Tashkent who provided one of the most outspoken accounts of the corruption of $q a d \overline{i s}^{94}$ was no doubt a man in the habit of making hasty judgments:

The Tadjiks and Uzbeks are readily distinguished from each other, not only in appearance but also in character. The Tadjik is larger and fuller in person, with an ample black beard, and with an air of shrewdness and cunning. He is fickle, untruthful, lazy, cowardly, and boastful, and in every way morally corrupted. ${ }^{95}$

91 A. Wilde, What is Beyond the River? Power, Authority and Social Order in Eighteenth and Nighteenth-Century Transoxiana (Vienna: Press of the Austrian Academy of Sciences, 2016): 67-80; G. Arendarenko, Bukhara i Afganistan v nachale 8o-kh godov XIX veka (Moscow: Glavnaia redaktsiia vostochnoi literatury, 1974): passim; D.N. Logofet, Bukhara: Strana bezspraviia (St. Petersburg: V. Berezovskii, 1909): 53; G.Iu. Astanova, "Dokumenty iz arkhivov Uzbekistana po istorii Tadzhikistana XIX-nachala XX veka." oNU (1991, no. 8): 57 .

92 Anon., Jung, ms Tashkent, TsVRUz, no. 6102: foll. 109b; 115ob-116. See also The Personal History of a Bukharan Intellectual. The Diary of Muhammad Sharîf Șadr-i Ziyā, trans. R. Shukurov and ed. E. Allworth (Leiden: Brill, 2004): 152-53, where Șadr-i Diyā' refers to the donations that his uncle Ināyatallāh received following his appointment to the post of ra'is in Qarshi.

93 S.A. Dudoignon, "La question scolaire a Boukhara et au Turkestan russe, du "premier renouveau" a la sovietisation (fin du XVIII ${ }^{\mathrm{e}}$ siecle-1937)." cMR 37/1-2 (1996): 143 .

94 Schuyler, Turkistan: Notes of a Journey in Russian Turkistan, Khokand, Bukhara, and Kuldja: 1: 169 .

95 Ibid.: 108. 
The third point that needs to be addressed in considering accusations against qadīs pertains to elementary Quellenkritik. Trusting the detractors of qā dīs leads to the reinforcement of the common colonial assumption that native judges always enjoyed discretionary powers. ${ }^{96}$ This approach is misguided, and we would do well to disentangle the intentions behind each accusation of corruption leveled against qadīs. Central Asians soon came to understand that charges of bribery were a powerful way of attracting the attention of the colonial authorities. It was common knowledge that Russians were always eager to listen to the colorful details of native judges' purported dishonesty, about which we find countless extravagant stories in the archives. Let us consider the case of Tīnī A Āy, a Kazakh widow living in a "nomadic encampment" (Chag., avil, Russ., aul) in the raion (district) of Jizzakh. After her husband died, she had an affair with a man and, from this relationship, gave birth to a boy. Two women of the same encampment wanted to remarry her to another man, but Tīnīq Ây did not comply with their wishes. The two women decided that Tīnīq Ây deserved to be punished: they came to her house, assaulted Tīnī Ầy and her mother, and strangled the baby in cold blood. It was probably for fear of other violent forms of retaliation that Tīnīq Āy did not file a claim against them. Instead, she turned to the colonial authorities, recounted only in passing her baby's murder, and concocted the story of being harassed by a native judge $(b \bar{\imath})$ and giving him fifteen rubles to let her go. It did not take long for the Russians sifting through the witnesses' statements to discover that the accusations of bribery (vziatochnichestvo) had been made up to draw attention to the brutal murder. ${ }^{97}$

Most such accusations were found groundless by both Russian prosecutors and Muslim judicial assessors. Let us consider, for instance, an admission (iqrār) of false accusation against a native judge. The background to the text is as follows. A certain 'Alī Khwāja had sued Muhyī al-Dīn Khwāja for malpractice. The plaintiff's uncle, Manșūr Khwāja, and the respondent owned several plot of lands in an area called Qizil Qurghān, east of Tashkent, which was particularly suitable for agricultural purposes because it was watered by

96 "Native judges enjoy too much power, and they often abuse their authority, especially by ruling arbitrarily against the weak (narodnye sudy imeiut slishkom mnogo sily i neredko zloupotrebliaiut svoei vlastiu, dopuskaia proizvol' i nasilie nad slabym)," N.S. Lykoshin, "Kazii (Narodnye sud'i): Bytovoi ocherk osedlogo naseleniia Turkestana." In Russkii Turkestan:Sbornik 1. Prilozhenie kgazete "Russkii Turkestan" (Tashkent: Tipografiia "Russkii Turkestan," 1899): 95 .

TsGARUz, f. I-21, op. 1, d. 752, 1l. 2-11. 


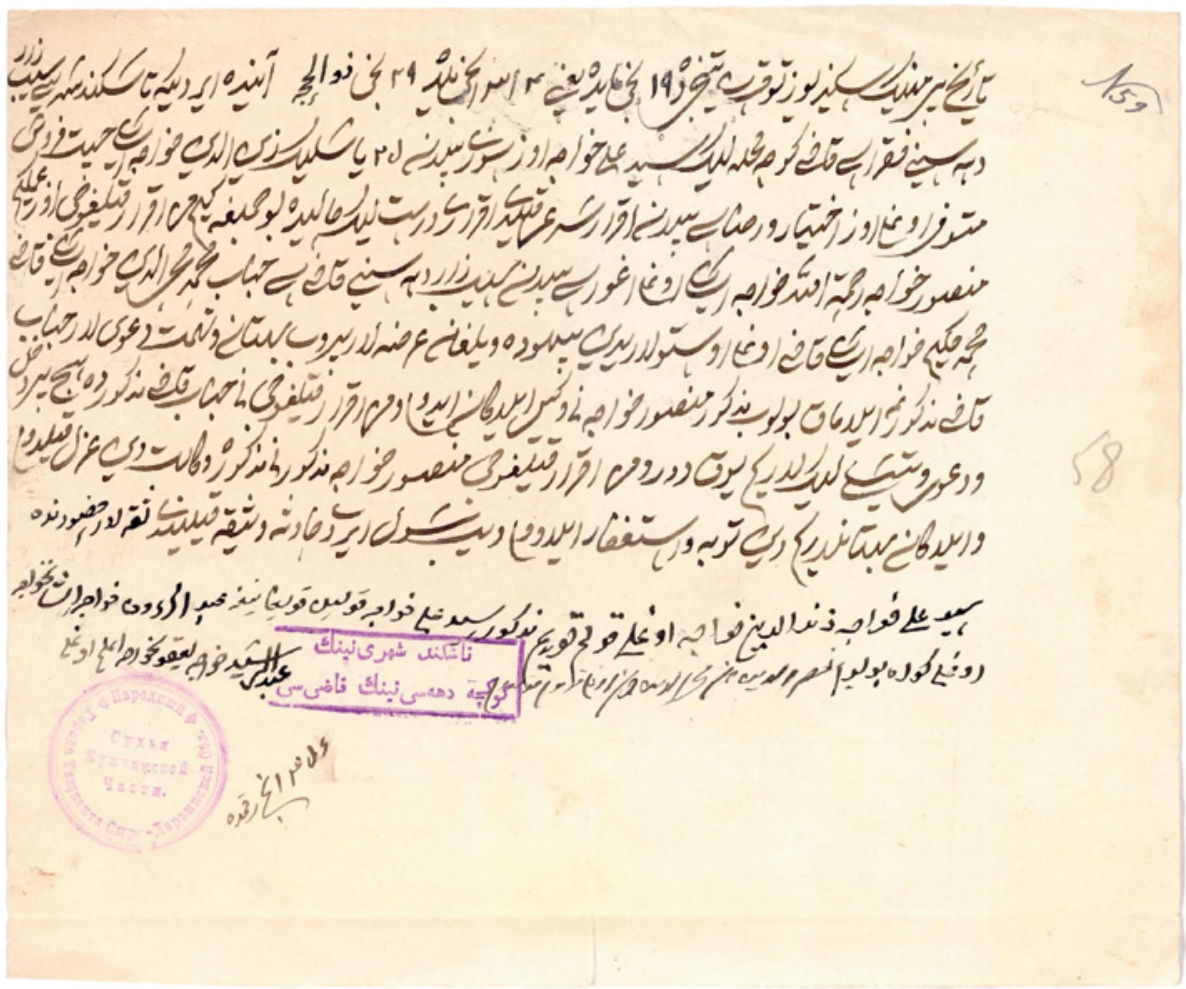

FIGURE 9 'Alì Khwāja admits that his lawsuit against the qāḍī Muhyī al-Dīn Khwāja was driven by malice and repents before a native court, 19.06.1897. TsGARUz, f. I-164, op. 1, d. 7, l. 58 . COURTESY OF THE CENTRAL STATE ARCHIVE OF UZBEKISTAN

several streams. ${ }^{98}$ Hoping that Muhyī al-Dīn Khwāja would be dismissed from office and forced to sell part of his estates, Manșūr Khwāja concocted a case against him and persuaded his nephew to file a claim against the $q \bar{a} d \bar{l}$. The Russian administration found that the case was driven by malice. Muhyì al-Dīn Khwāja, however, requested that the plaintiff admit that his claims were illintentioned. He therefore dragged him into another native court, where a $q \bar{a} d \bar{\imath}$ notarized 'Alì Khwāja's admission of false allegations and repentance. What follows is the certificate notarized by the qāḍ̂̀ and that Muhyī al-Dīn Khwāja preserved in his personal archive [Fig. 9]. ${ }^{99}$

98 TsGARUz, f. I-164, op. 1, d. 6, l. 62.

99 TsGARUz, f. I-164, op. 1, d. 7, l. 58. 
On 29 Dhū al-Hijja 1314 [19.05.1897] 'Alī Khwāja stated he is the 25-yearold son of the deceased cloth merchant Zayn al-Dīn Khwāja Īshān, citizen [fuqarā] of the Sibzar district [and inhabitant of] the Qāḍi Khwāja mahalla [neighborhood]. Of his own will, he acknowledged in a just way that, at the instigation [ighwāsì bìlān] of his uncle Manșūr Khwāja, son of Rahmmatallāh Khwāja İshān and acting on behalf of the latter, he had submitted false petitions [bīhüda wa yalghān 'aridalär] conveying slanderous claims [buhtān wa tuhmat da'wālār] against the qāḍ̂̀ of the Sibzar [district], Muhammad Muhyī al-Dīn Khwāja İshān, son of Muhạammad Ḥakīm Khwāja Īshān Qāḍi Kalān. The acknowledger has no claims against or any relationships with the aforementioned $q \bar{a} d \bar{\imath}$. He also dismissed himself from the capacity of proxy of Manșūr Khwāja and repented his futile actions [tawba wa istighfär aylādūm]. This event was registered in the presence of trustworthy people. Sayyid 'Alī Khwāja, son of Zayn al-Dīn Khwāja signed; 'Abd al-Ra'uf Khwāja, son of İshān Khwāja witnessed the signature of Sayyid 'Alī Khwāja. Nașr al-Dīn Khān, son of Bahr al-Dīn Jān, signed. Seal: Qāḍī of the Kukcha district, city of Tashkent. Signature: 'Abd al-Rashid Khwāja Ya'qūb Khwāja A'lam-ūghlī.

Under Russian rule in Central Asia, "appeals" (Pers., 'arḍ/'arida, Russ., proshenie) became an effective tool in the hands of the local Muslim population. Even under the khans, of course, Central Asians had been able to pursue redress by appealing directly to the central authority, thereby involving the rulers in their conflicts. With the advent of colonization, however, there was now a broad range of new means through which to reach the rulers. First, the initiatives of Muslim appellants were less restricted by the scribal rules of Islamic compositional genres. While, in the Bukharan emirate or the khanate of Khiva, petitions were usually submitted orally or, at best, translated by muftis' assistants into a protocol of claim (mahdar), under colonial rule locals enjoyed ample opportunity to craft their petitions by using their imaginations. Those who were literate might draft these materials themselves; those who were not could hire a scribe or a translator to produce a petition in Chaghatay, the language in which Central Asians were expected to correspond with the colonizers. Many Muslims chose to have their appeals written directly in Russian. Producing and submitting a petition did cost money, of course, but it seems to have cost considerably less than what was usually levied under Muslim principalities to 
hear a case:100 as we have seen, muharrirs charged for crafting a protocol of claim, trustees and court attendants levied fees for their services (farsakh pulī) khidhmatāna), and qādìs expected a gift when they took charge of a claim. And when a claimant lived far from the seat of power and initiated a case, she often had to feed the trustee and his retainer as well as the local notables who acted as mediators. ${ }^{101}$ Filing a petition with the Russian administration, by contrast, cost only 60 (later 80 ) kopeks. ${ }^{102}$

When evaluating the petitioning system involving Muslims in the colony, we should also consider that colonial officials were less concerned with the possibility that their petitioners lied than eager to trust accusations against judges' malpractice. This stood in stark contrast to the attitude that the khans and their courts had towards appellants whose knavery and mischief were, instead, the object of sanction. In order to appreciate this contrast in full, we should now turn to the areas of Central Asia in which colonial administrative arrangements were in close contact with the older system of the khans. One of those areas is Khorezm. Following the siege of Khiva in 1873, a treaty between the Russians and the Qunghrat dynasty led to the partition of Khorezm into two political and administrative entities: on the right bank of the Amu-Darya, the Amu-Darya Department (Amu-Dar'inskii Otdel) was established as one of the provinces of the Governorship-General of Turkestan, while in an area on the left bank of the river the khan retained the prerogatives of political independence under a formal regime of protection.

The new administrative division of Khorezm did not restrict the movement of goods and people across the Amu-Darya; legal and fiscal arrangements introduced in the Amu-Darya Department allowed the preservation of the social fabric of the region. One such arrangement regulated the resolution of disputes between citizens living on opposite sides of the river and stipulated that lawsuits filed in Petroaleksandrovsk — which involved as defendants individuals inhabiting the Khanate of Khiva-would be processed by the Qunghrat authorities. In other words, if somebody in the Amu-Darya Department filed

100 TsGARUz, f. I-125, op. 1, d. 498, ll. 65-64-64ob. A Khorezmian governor informs the royal court in Khiva about the complex and unexpected developments of a case of unpaid debts. During a hearing, the plaintiff had complained about the $q \bar{a} d \bar{l}$, and the judge later expressed the desire to turn with the defendant to the royal court in Khiva. The governor tried to dissuade them from doing so because filing a lawsuit there would cost a considerable sum of money.

101 TsGARUz, f. I-125, op. 1, d. 498, l. 84.

102 Morrison, Russian Rule in Samarkand, 1868-1910: A Comparison with British India: 184. 
a lawsuit in the chancellery of the commandant in Petroaleksandrovsk, which was the administrative seat of the Otdel, the Russian official would have this petition translated and redirected to the khan in Khiva. This precipitated a cascade of administrative events in the protectorate: the Qunghrat ruler would process the legal cases on the basis of a principle on territoriality and thus hand over the documentation to one of his provincial governors, who would involve other levels of local administrators: community leaders, tribal headmen, village elders, and so forth. The latter were required to investigate the charges against the subjects of the khanate and report to the governor, who would in turn report to the khan, who was expected to get back to the Russian official in Petroaleksandrovsk. This bureaucratic machinery is of great interest to us because it produced documentation that indicates that the Qunghrats perceived a change in legality among the Muslims who lived under Russian rule.

One of the side effects of this bureaucratic procedure was the increasing number of lawsuits, filed in the office of the Russian official, that the Qunghrats discovered to have been driven by malice. Early in the history of the partition of Khorezm, only 12 years after the siege of Khiva, we find Muhammad Rahīm Khān II warning the Amu-Darya Department that Muslims there were submitting false petitions ( $y \bar{a}$ lghān 'arḍlār) and that it was difficult for the Qunghrat authorities to hear such cases because the claimants usually dismiss the authority of $q \bar{a} d \bar{c} \bar{s}$, do not show up in court, and even calumniate judges and governors. ${ }^{103}$ The Russians appear not to have taken counter-measures to this new legal phenomenon, instead dismissing such warnings as irrelevant. The correspondence across the Amu-Darya River illustrates instances in which the Khivan authorities, with a dose of irony, reported to the Russians that, in listening to the words of deceivers, the colonizers were actually conferring a flimsy authority on false accusations and malign imputations. Such instances are best exemplified by cases of Muslim family law. We find, for example, that a Kazakh from Krasnovodsk filed a lawsuit against a Khivan subject, claiming that the latter had abducted his wife and his two children. The investigation in Khiva found that the woman had already obtained an irrevocable divorce from the claimant in consideration of a sum of money and that the couple had, in fact, never had children. ${ }^{104}$ Another Kazakh petitioned the Russians seeking restitution of the dowry following an engagement to a Kazakh woman from

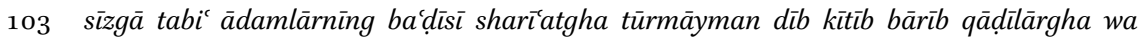
hākkimlärgha tuhmat qülīb, 02.06.1885, TsGARUz, f. I-125, op. 1, d. 29, l. 700 .

104 TsGARUz, f. I-125, op. 1, d. 19o, ll. $36-38$. 
the protectorate, which, he argued, had never resulted in marriage. The investigations revealed a different story: seven years earlier, the woman had engaged herself to another man before several witnesses and had been married to him for two years. The authorities in Khiva were thus adamant that the claim was slanderous (buhtān wa yālghān). ${ }^{105}$ In a somewhat different story, a Kazakh claimed before a Russian official in Petroaleksandrovsk that her daughter had been abducted. According to the claimant, the abductor was someone living under the jurisdiction of the Khivans. The defendant was able to prove that the suspect had indeed kidnapped the girl and taken her to Chimbay, and there the two had contracted a legal marriage before a $q \bar{a} d \bar{l}$, before a cohort of notables acting as witnesses and with the consent of the girl's parents, including the claimant! And the couple had a two-year-old daughter. Again the Khivan authorities concluded that the petition was a case of mischief (buhtān).$^{106}$

One wonders whether the repeated use of the term "slander," which so often appears in the terse bureaucratese of the Qunghrats, prefigured some kind of instrumental purpose. It is one thing to qualify a claim as null but a completely different thing to assert that the statement of a claimant is injurious and defamatory. Not only do we encounter the categories of "null and void" ( fäsid wa bäțil) in the sites of application of sharía and in the records written in the Islamic juristic idiom, but we also find that Khivan bureaucrats too were conversant with these notions and used vernacular equivalents such as $b \bar{\imath} k \bar{a} r^{107}$ and $n \bar{a}-r \bar{a} s t^{108}$ to replace Arabic juristic terms such as fäsid wa ba ạtil and could thus clearly explain that certain claims were unsound. It is easy to find cases of such bureaucratic conduct. For example, in one letter of instruction (fatak), the Khivan royal court orders a bailiff and a retainer to escort the parties to a dispute before the khan in order that their dispute be resolved. On the verso of the fatak, we learn that nine days after this notification, during the hearing in Khiva, the plantiff admitted that the claim was unfounded (da'wāmni büshqa qūydūm dīb iqrār). ${ }^{109}$

It would thus be misleading to assume that, outside the Russian sphere of influence, Khorezmians did not petition their ruler with grievances that were later never substantiated and were therefore voided. Instead, the emphasis

\footnotetext{
105 Ibid.: 1l. 13-14ob. See also TsGARUz, f. I-125, op. 1, d. 81, 1. 5ob.

106 IQM, P-8, KP 3674, ll. 33-33ob: qīzìmnī wa māllārīmnī qāwub àlīb kìtdīlār dīgānī sūzì buhtāin dūr.

107 TsGARUz, f. I-125, op. 2, d. 633, l. 930b; 110ob; 1110b.

108 Ibid.: l. 130ob.

109 TsGARUz, f. I-125, op. 2, d. 633, ll. 95-95ob. For a similar case, see ibid.: ll. 39-39ob; ll. $98-98$ ob.
} 
placed on the category of "slander" should alert us that we are here dealing with something different- that is, a moral judgment qualifying the behavior of those appellants who were purposefully submitting false petitions to the Amu-Darya Department. ${ }^{110}$ In other words, the Qunghrats were signaling that, although the arrangements introduced by the Russians in Khorezm largely preserved the traditional institutions of equity, they also brought about a major change in Muslims' legal consciousness and hence in their morality. The Russians tolerated the locals' many false petitions. It thus seems that the Qunghrats did not limit themselves to admonishing the Russians that their subjects were submitting claims that were to be voided but that they indicated that some Muslims living on the other side of the Amu-Darya were now maliciously submitting false petitions. The Khivan authorities were pointing out the obvious limits of the new institutional arrangement that allowed such behavior.

If so, one would like to know what prompted the Muslims, mainly Kazakhs, living in the Amu-Darya Department to undertake such courses of action and indulge in practices that would have been censured in the protectorate. What was slander in Khiva had now become in Petroaleksandrovsk only a claim to be voided. This qualitative shift in interpreting false allegations must have depended on several factors. First, submitting a petition to Petroaleksandrovsk was less costly that obtaining an audience at the royal court in Khiva, for the reasons given above. Second, Muslims must have had a general perception of impunity in the areas of Russian rule; third, and most important, was the varying publicity surrounding the procedure of filing claims on the opposite sides of the Amu-Darya. For those who had made themselves a bad name, obtaining an audience at the royal court must have been difficult; even more difficult would have been to prevent their reputation from reaching the authorities involved in the application of royal justice. Things were very different in the blind bureaucratic machinery of the Russian Empire, where such factors as fame and notoriety counted for little.

We now return to Tashkent to examine another interesting aspect of the culture of lies that had spread after the establishment of colonial rule. It was often the case that the Russian colonial masters and their Central Asian subjects would make a strategic alliance to undermine the credibility of the qādìs. In doing so, the respective parties sought different goals. The colonizers pursued

110 For a local use of the term buhtān, see TsGARUz, I-125, op. 2, d. 633, l. 32. 
a cultural project that consisted of establishing the moral superiority of their tribunals vis-à-vis the native courts. Locals, by contrast, were more concerned with pursuing financial gains.

Let us consider an episode involving an alleged forgery that occurred in Tashkent approximately fifteen years after the Russian takeover. In late December 1881, a man named Bāy Bābā Turabāy-ūghlī111 was on his deathbed. He summoned his grandson Dhākir Jān and asked him to act on his behalf to establish a charitable endowment (waqf). On 25 December, the young man appeared in the native court presided over by Muhyī al-Dīn Khwāja, who notarized a deed according to which Dhākir Jān, by virtue of his power of attorney (wakil), established a waqf, dedicating the income from six shops to two mosques. This evidently upset several potential heirs.

There are some unconventional elements in the "endowment deed" (vakufname, Pers. waqf-nāma). First, it appears that the qā ( tafwì d) to stipulate the conditions (shurüț) for administering the waqf. Second, the name of the administrator (mutawallī) who was to oversee the endowment is not given in the document. We read instead that the administrator was to be appointed by the person who had the authority to make decisions regarding the administration of the endowment (mutawalli-yi madhkūr mansūub bāshad az qibal-i man lahu al-wilāya), namely, the $q \bar{a} \operatorname{dit}_{\overline{1}}{ }^{112}$ These apparently minor points are important. The inclusion of these stipulations in the waqf deed formally excluded the relatives of the founder from receiving a share of the revenues produced by the shops. From this point of view, the deed seems to attest to an act of piety: Bāy Bābā established a waqf exclusively for charitable purposes, without attempting to promote a descent group by appointing one of his descendants as administrator of the endowment, ${ }^{113}$ but not all the members of his family praised Bāy Bābā for this display of piety. His nephew Șādiq Jān claimed that the qā dị Muhyī al-Dīn Khwāja, together with Dhākir Jān, had concocted a stratagem to divert Bāy Bābā’s properties from his close relatives and get hold of a portion of the waqf's revenues. ${ }^{114}$

\footnotetext{
111 In Russian, Baibaba Turabaev.
}

112 The endowment deed is available in TsGARUz, f. I-17, op. 1, d. $32607,1.3$.

113 More often than not, Central Asian endowment deeds stipulate that the office of administrator be assigned to the son of the founder of the waqf and inherited by his agnates $(a w l \bar{a} d)$, thereby favoring the creation of a "family trust." On this point, see M.E. Subtelny, Timurids in Transition: Turko-Persian Politics and Acculturation in Medieval Iran (Leiden: Brill, 2007): 150-1.

114 Disinheriting one's relatives might also have been perceived by many as immoral, and there is a good chance that most people in Tashkent would have been on Ṣādiq Jān's side in the dispute. See Chapter 4. 
The following is an excerpt from an appeal that Șādiq Jān submitted to the governor-general of Turkestan at the beginning of May 1890. The document marks the beginning of the family drama:

When he departed, my brother [sic] Bāy Bābā Turabaev left six shops in the Tashkent bazaar in the eastern part of the city. These shops belong to a waqf, and their revenues belong to me, because I am the heir to the endowment [kak naslednik vakufa]. For unknown reasons, the qādì of Sibzar ${ }^{115}$ has appointed himself to the post of administrator [mutavaliem] and is exploiting the incomes generated by the endowment; he has rented the shops for twenty rubles a year for the last seven years. [In addition] I lent him 110 rubles, which I should not have given. He has kept the endowment deed [vakuf-name], even though he is not a relative of Turabaev and cannot fulfill the duty of administrator; according to the deed, it is I who should act in this capacity. ${ }^{116}$

The document was compiled in Russian and signed by Ṣādiq Jān, who was illiterate. ${ }^{117}$ Ṣādiq Jān must, at that time, have had access to the services of a scribe. The short appeal is peppered with vernacular terms-mutavali (Ar. mutawallī) for "administrator," vakuf-name (Pers. waqf-nāma) for "endowment deed," and kazi (Ar. qā author must either have been acquainted, albeit superficially, with the Islamic institutions involved in the case and/or unable to render these vernacular terms into Russian. In any event, the author of this document seems to have adopted various expedients in order to streamline the process of composition.

Be that as it may, Saadiq Jān probably presented himself to the scribe as one of the direct heirs of the founder of the waqf and stated that he was thereby entitled to the position of administrator, a position that, he claimed, had been usurped by the judge Muhyī al-Dīn Khwāja. Had the endowment deed stipulated that the post of administrator should pass from the founder to his heirs, Șâdiq Jān would have had good reason to emphasize his agnatic relation to Bāy Bābā. Indeed, the position of administrator entailed, along with the main duty - to safeguard and increase the wealth of the endowment—-the right to

115 This was the name of the city district in which the qạ dị Muhyī al-Dīn Khwāja was working.

116 Proshenie, 03.05.189o, TsGARUz, f. I-17, op. 1, d. 4887, l. 48.

117 In another appeal filed with the Russian administration, Ṣādiq Jān stated that he was illiterate and requested that another person sign for him (Șädiq Jān Ākhün Jān-üghlī khațt bīlmagān ūchūn Bābā Bīk Nār Būta Bīk-ūghlī qūlūm qūydūm); cf. Proshenie, 30.12.1891, ibid.: l. 2 ob. 
a share of its revenues, that is, a salary (haqq al-tawlīya). The expression "heir to the waqf" is thus clearly a misunderstanding; the scribe misconstrued the forceful argument that Ṣādiq Jān intended to use to uphold his putative rights.

Even more striking is that the appeal was submitted to a Russian administrative authority rather than to a Muslim one. The argument embedded in it presupposes that its addressee would know that, in Central Asia as elsewhere in the Muslim world, most Islamic endowments were not genuinely charitable but were instead established to circumvent the Islamic law of succession. A person who owned property and did not want it to be divided among his heirs - or dispersed, if his female relatives married — could establish a waqf and stipulate that it be administered by a family member. In this way, the property in question would remain under the family's influence. ${ }^{118}$ It is unlikely that the Russian official who received the petition would have been expected to know all this and to interpret the appeal as intended.

The other allegations in the petition are plainly false. Muhyī al-Dīn Khwāja had never acted officially as administrator: by the conditions stipulated by the founder of the waqf, he was empowered in his capacity as qã $\bar{l} \bar{l}$ to appoint a person to act as administrator of the endowment. Therefore, the accusation that he had usurped the post and squandered the waqf revenues was baseless. In fact, as I hope to show, he could not have done this, as he did not have direct access to the waqf revenues. In addition, Șādiq Jān was not automatically entitled to be appointed administrator, because access to the latter office was regulated instead by the $q \bar{a}$ dì. Finally, as became clear later, Șādiq Jān had a history of bitter disputes with the Muslim judge: not long before, he had accused Muhyī al-Dīn Khwāja of extorting money from him. That accusation proved false and driven by malice. ${ }^{119}$ This record shows how a $q \bar{a} d \bar{l}$ assessed an appeal that Ṣādiq Jān had submitted to the Russian authorities accusing Muhyī al-Dīn Khwāja of extortion. Șādiq Jān opted for the Russian court of appeals but was unable to produce evidence to support his charges. The report indicates that the $q \bar{a} d \bar{\imath}$ discovered that Muhyī al-Dīn Khwāja had previously removed Ṣādiq Jān from the guardianship of his underage brother after a case of embezzlement. This

118 On this subject, see A. Layish, "The Mālikī Family waqf According to Wills and waqfiyyāt." BsoAs 46/1 (1983): 1-32; idem, "The Family Waqf and the Sharīa Law of Succession in Modern Times." Journal of International Law 4/3 (1997): 352-88; idem, "Waqfs of Awlād al-Nās in Aleppo in the Mamluk Period as Reflected in a Family Archive." JEsHo 51/2 (2008): 287-326; D.S. Powers, "The Maliki Family Endowment: Legal Norms and Social Practices." IJMES 25 (1993): 379-406.

119 Qāọī of Zangi-Ata to the military governor of Syr-Darya Province, 19.01.189o, TsGARUz, f. I-164, op. 1, d. 23, l. 26. See below, Appendix IV. 
was apparently the reason that Ṣādiq Jān had taken legal action against Muhyī al-Dīn Khwāja.

What prompted Șādiq Jān to file a groundless appeal? Why was he willing to risk making statements that could easily be shown to be false? What was he trying to obtain? As I hope to show, Șādiq Jān, like many Central Asian Muslims, knew that colonial officials were convinced that $q \bar{a} d \bar{l} \bar{s}$ were incompetent and corrupt and was attempting to use this stereotype to his advantage. ${ }^{120}$ Like many before and after him, Ṣādiq Jān was trying to appropriate the discourse on the Islamic judiciary produced by the colonial administration in order to manipulate the Russians who would rule on his appeal.

Initiating legal action against Muhyī al-Dīn Khwāja would have been fairly easy. ${ }^{121}$ Russian authorities had placed the $q \bar{a} \underline{d} \bar{\imath}$ under intense scrutiny soon after they installed themselves in Tashkent. Like his father, ${ }^{122}$ Muhyi al-Dīn Khwāja had collaborated with the Russians in the aftermath ${ }^{123}$ of the conquest, in various capacities. Most notably, under the stern rule of GovernorGeneral Cherniaev, in $\mathbf{1 8 8 4}$ he had headed a special commission established to create a spiritual administration in Turkestan on the model of the one in Ufa. ${ }^{124} \mathrm{He}$ had also received several awards for his positive attitude toward the colonizers. ${ }^{125}$ As time passed, however, the Russians became increasingly concerned at the moral authority that he enjoyed among the locals, an authority that resulted in large part, they suspected, from the privileged standing that they themselves had granted him. The following is an excerpt from a

120 Morrison, Russian Rule in Samarkand, 1868-1910: A Comparison with British India: 272.

121 I know of at least other three instances in which investigations proved that legal actions taken against Muhỵī al-Dīn Khwāja were driven by malice and personal hatred: the report of a judgment (hukm) issued by a council of qāḍis, 31.07.1886, TsGARUz, f. I-164, op. 1, d. 6, l. 73; an acknowledgment (iqrār) of repentance (tawba wa istighfār), 19.05.1897, TsGARUz, f. I-164, op. 1, d. $7,1.58$; a copy of a report from the council of qā dant, 1899, ibid.: 68. See also TsGARUz, f. I-17, op. 1, d. 5387, 5775, 6367, 6469 .

122 Biografiia Tashkentskogo uchenogo Seid Mukhammed Khakim Khodzha (Otets Kaziia Mukhitdina), f. I-164, op. 2, d. 2a, ll. 1-15ob.

123 On Muhyī al-Dīn replacing his father in the post of qāọ̄ in January 1870, see TsGARUz, f. I-36, op. 1, d. 725, ll. 1-3. He was appointed to the post ex officio by the Russians.

124 TsGARUz, f. I-1, op. 1, d. 326.

125 Posluzhnoi spisok na Kaziia Sibzarskoi chasti g. Tashkenta, n.d., TsGARUz, f. I-17, op. 1, d. 6468, ll. 143-143ob. The document was produced at the request of the prosecutor of SyrDarya Province; see his correspondence with the Tashkent city commandant, 29 Nov. 1897, ibid.: 1. 149. See also the awards issued by the chancellery of the governor-general and Alexander III in 1875 and 1891 respectively, TsGARUz, f. I-164, op. 1, d. 5, l. 8, 2. 
confidential report ${ }^{126}$ on Muhyī al-Dīn Khwāja, which the Tashkent city commandant wrote at the request of the military governor of Syr-Darya Province:

When the elections to the office of native judge were introduced, the inhabitants of Sibzar voted for Muhyī al-Dīn [Khwāja], in view of the facts that he was an influential indigene among the Russians and that the title of $q \bar{a} d \bar{\imath} \bar{w}$ was a hereditary prerogative in [his] family. [...] The great powers that the law [zakon] confers on the native judge and the uncontrolled authority [the latter enjoys] in levying taxes strengthened, to a certain extent, the importance that Muhyī al-Dīn [Khwāja] has among [his] people. [...] In the eyes of the Russians, Muhyī al-Dīn Khwāja became a distinguished man because of the careful fulfillment of all his duties, as well as his manifest tolerance for every innovation, which inevitably changed entirely the lifestyle of the locals, who were forced to accustom themselves in one way or another to the new cultural influences [of the Russians. Be that as it may], in his milieu, Muhyī al-Dīn Khwāja remained the strict guardian of rigid Muslim traditions: he zealously performs the religious rituals and instills in the conscience of his fellow citizens the conviction that his apparent devotion to the Russian government is stimulated by nothing but the need to render assistance to his people, defend the interests of the latter in the face of the Russian government, and hinder the Russians' efforts to change the life of the Muslims. [...] All this persuades me that the reelection of Muhyì al-Dīn Khwāja to the office of native judge is not desirable, and it is better, in my opinion, to refuse the services provided by this undoubtedly cultivated indigenous man. ${ }^{127}$

This passage illustrates how the most influential representatives among the military officers of the Russian administration monitored the activity of this powerful $q \bar{a} \mathfrak{d} \bar{i}$. Most notably, the author of this report had reviewed several cases in which legal action was taken against Muhyī al-Dīn Khwāja. On one such occasion, the official acknowledged that, "[the $q \bar{a} d \bar{l}]$ knows how to make use of the shari $a$, and he was able to acquaint himself with the norms of our [i.e., Russian] law to such an extent, that, to prove him guilty in any case of misconduct turned out to be extremely difficult; he knows how to adorn every injustice in legal dress." 128

126 Raport, 24.03.1893, TsGARUz, f. I-36, op. 1, d. 3367, ll. 13-22ob.

127 Ibid.: 1l. 15, 21-210b.

128 Ibid.: 1l. 20-20ob. 
While it might have been possible for colonial officials to voice contempt for the $q \bar{a} d \bar{l} \bar{s}$, it was no easy task to convince an administrator to prosecute a specific $q \bar{a} d \bar{\imath}$ on charges of criminal malpractice. The colonial state was a multifaceted entity, and the success of an appeal depended to a great extent on the reaction of the particular administrator who had to deal with it. Those who staffed the lower levels of the administration-city commandants and the like-were used to baseless accusations and knew that many of the appeals that landed on their desks were without grounds. It is little wonder, then, that Ṣādiq Jān's appeal was quickly deemed groundless and was rejected. In the event, however, the rejection was unduly hasty. The Tashkent city commandant, Stepan Putintsev, overlooked the fact that Șādiq Jān's appeal contained two different complaints: one regarded the waqf, the other extortion. Putintsev knew that Muhyī al-Dīn Khwāja had been acquitted, some months earlier, of extortion when Șādiq Jān had been found to be motivated by a desire for revenge. ${ }^{129}$ When he saw the appeal to the governor-general, the city commandant probably thought that Șādiq Jān's complaints regarding the waqf were merely another attempt to discredit Muhyī al-Dīn Khwāja. This is probably why Putintsev recommended that the provincial chancellery (oblastnoe uprav(enie) dismiss the case. ${ }^{130}$ As we shall see, Putintsev was correct, but the chancellery was not satisfied with his assessment and instructed the commandant to produce additional evidence. Consequently, at some time before the end of May 1891, Putintsev asked his assistant, Artillery Captain Nil Sergeevich Lykoshin, ${ }^{131}$ to question everyone involved in the case.

When questioned by Lykoshin, Ṣādiq Jān declared that his uncle Bāy Bābā had called for him a few days before his death and had said, in the presence of two witnesses, that he intended to establish a waqf in support of two mosques, that the endowment would consist of six shops he owned, and that he wanted Ṣādiq Jān to be the administrator. Ṣādiq Jān admitted he had never seen the waqf deed, but he staunchly maintained that his uncle had proceeded as he had said he would. Șâdiq Jān then went on to discuss the charges of extortion he had brought against Muhyī al-Dīn Khwāja. He claimed the qā dī had obliged him to pay 110 rubles, a demand with which Șādiq Jān complied for fear of Muhyī al-Dīn Khwāja's power and influence. Russian administrators were convinced that Islamic courts were dysfunctional and corrupt, and the abuse of

\footnotetext{
129 TsGARUz, f. I-164, op. 1, d. 23, l. 26.

130 City commandant to the provincial chancellery, 18.01.1891, TsGARUz, f. I-17, op. 1, d. 4887, l. 49 .

131 See A. Morrison, "Sufism, Pan-Islamism and Information Panic: Nil Sergeevich Lykoshin and the Aftermath of the Andijan Uprising." PP 214 (2012): 262-64.
} 
power by $q \bar{a} d \bar{l}$ s was a leitmotiv of their view of judicial malpractice. Șādiq Jān was evidently playing on this by attempting to depict Muhyī al-Dīn Khwāja as a man who had taken advantage of his position to enrich himself.

In order to verify Ṣādiq Jān's claims, Lykoshin inspected the shops that were endowed in favor of the two mosques. It turned out that the administrator of the waqf was a man named Maqsūm - the imam of one of the two mosqueswho had been appointed to this post by the qā had the deed establishing the waqf, which he showed to Lykoshin. The document stated clearly that Bāy Bābā had dedicated his six shops in favor of the two mosques and that the person who helped him to do so was his grandson, Dhākir Jān. Lykoshin was also able to clarify that the deed did not stipulate that the descendants of the founder of the waqf were to be appointed to the post of administrator. Lykoshin wrote, "The deed does not include any stipulation with regard to this and therefore, according to $\operatorname{shari}^{-} a$, the right to appoint the mutawalli belongs to the $q \bar{a} d \bar{l}$, who can hold elections in the neighborhood (mahalla) or consult members of the community."

The Russian official was willing to reason in the manner of a Muslim jurist in order to define what should be considered right or wrong with regard to the stipulations in the waqf-nāma. Apparently, notions emanating directly from the notary practice of shari $a$ courts shaped substantially the investigations carried out at the lowest level of the colonial administration. Lykoshin established that Muhyī al-Dīn Khwāja had acted as he was supposed to. The previous year, in keeping with the stipulations set forth in the waqf-namma, he had appointed an administrator (mutawallī), Maqsūm. Since then, although the revenues generated by the shops had nearly doubled, all the money had gone to refurbishing them and none to the administrator. Having established that Șādiq Jān's allegations regarding the waqf were groundless, Lykoshin became convinced that Ṣādiq Jān's claims of extortion perpetrated by the quậi were also unfounded.

Given that, Ṣādiq Jān had made similar accusations on a previous occasion, Lykoshin decided that this present claim was merely a further attempt to discredit the $q \bar{a} d \bar{l}$ and recommended closing the investigation. He wrote: "I am convinced that Șādiq Jān is not in a position to justify the lawsuit regarding the 110 rubles and is unable to support his claim that he should be appointed to the post of mutawalli."132

While his assistant was compiling this report, Putintsev decided to question Muhyī al-Dīn Khwāja himself. During that interview, the qā that it was Bāy Bābā who had decided to establish the endowment and that he

132 Act no. 69, 03.06.1891, TsGARUz, f. I-17, op. 1, d. 4887, ll. $42-45$. 
had wanted the imams of the two mosques to administer the revenues. Muhyi al-Dīn Khwāja also argued that the allegations of malpractice regarding the waqf were an attempt by Ṣādiq Jān to discredit him and gain votes for another candidate in elections to choose a judge. The qā reelection to office, none of the accusations had been repeated and argued that, if there had been any basis for them, the people responsible for the waqf would have gone to the authorities and complained about him. Muhyī al-Dīn Khwāja also explained that Ṣāiq Jān's attempt to compromise him had begun after the $q \bar{a} d \bar{\imath}$ had found him guilty of embezzling more than one thousand rubles while acting as guardian for his minor brother and had ordered him to repay the sum. Ṣādiq Jān, who had, for unknown reasons, managed to avoid paying, had, since then, been defaming the judge. ${ }^{133}$

By mid-May 1891 the city commandant had collected enough evidence to argue that Saadiq Jān's appeals to the Russian authorities were motivated by malice and should be rejected. It was at this moment, when Șādiq Jān had little hope of convincing the colonial authorities to hear his case, that Mayram Bībī, Bāy Bābā's daughter and Ṣādiq Jān's cousin, addressed a petition directly to the governor-general of Turkestan. This was part of a larger plot against the qādit, so the timing of the appeal, as well as the arguments, are important. On 7 June she wrote:

My father died ten years ago, leaving an inheritance that consists of [six shops] [...], no rubles, and other goods that amount to a value of 300 rubles. I am the direct heir to all this wealth. Nevertheless, I cannot make use of this inheritance because it seems that the $q \bar{a} d \bar{l} \bar{l}[\ldots]$ has crafted a document that says that my father dedicated everything to a waqf, while the latter was, in fact, nearly dead. I consider this document a forgery [vymyshlennym] because, at the moment of its production, my father was not fully in possession of his mental faculties. He was on his deathbed, as can be attested by several witnesses. For seven years, Muhyī [al-Dīn Khwāja] collected the revenues from the shops, and I do not know for what purpose he has used them.... Since Muhyī has been back in office as judge, he has collected the revenues. I ask that my inheritance be restored, that the revenues equivalent to 840 rubles generated by the rent be given to me, and that the $q \bar{a}$ d $\grave{\imath}$ be investigated for malpractice according to Russian law. ${ }^{134}$

133 Bayān-nāma, 11.05.1891, ibid.: 1. 50.

134 Proshenie, ibid.: 1. 31. 
It was once again Putintsev, the humble official on the bottom rung of the ladder of colonial command, who was assigned to deal with the petition. ${ }^{135}$ His findings were clear:

The appeal produced by Mayram Bībī Turabaeva is a copy without additions [bez vsiakikh izmenenii] of the appeal filed by her cousin Ṣādiq Jān. [Evidently] the latter wishes to be appointed to the post of mutawalli of the waqf established by the deceased Bāy Bābā Turabaev in support of two mosques. With regard to the content of the waqf deed, Ṣādiq Jān does not have the right to hold this office. [...] With this appeal, Mayram Bībì cannot produce any information regarding Bāy Bābā Turabaev's waqf, which was not produced earlier by Ṣādiq Jān, whose appeal was rejected. The latter has appealed repeatedly on his behalf; he is now using, instead, the stratagem of depicting his relative Mayram Bībī as the person entitled to the property endowed to the waqf. ${ }^{136}$

Putintsev asserted that Ṣādiq Jān had understood that there was no chance that his claim would be taken seriously, so he had approached his cousin and persuaded her to submit a petition. Putintsev recommended that the appeal should not be heard, but, again, he had acted too quickly. His decision was not backed by the highest bureaucrats, who might have felt that the commandant was siding with Muhyì al-Dīn Khwāja, thereby acting against the interests of his superiors. As we shall see in Chapter 5 with regard to cases of guardianship, opposing one's superiors could have harmful consequences.

Putintsev also overlooked the fact that Mayram Bībi was the first to claim that her father was not in full possession of his mental faculties when the endowment deed was notarized. Although her appeal was in Russian, Mayram Bībī was relying on an Islamic legal argument. In fact, before submitting her petition to the colonial authorities, she had secured a fatwa decreeing that the shops were not to be considered a waqf because, at the moment when he dedicated his properties to the mosques, Bāy Bābā was mortally ill (marad al-mawt). ${ }^{137}$ As explained by Ron Shaham, the question of mortal illness on which her argument rested is a concept developed by Muslim jurists that relies on the assumption that a person foreseeing his imminent death may be inclined to contract transactions relating to his property that prejudice the

\footnotetext{
135 Counsellor of the military governor to the city commandant, 24.06.1891, ibid.: 1. 33 .

136 City commandant to the provincial chancellery, 27.06.1891, ibid.: ll. 33ob.-34.

137 Undated legal opinion ( fatwā), ibid.: 1. 38. Four muftīs attached their seals to the document.
} 
rights of his legal heirs or creditors. To defend the latter, the jurists prescribe that any donation made by a person on his deathbed in favor of a legal heir is not effective unless approved by the other heirs after the ill person's death. ${ }^{138}$

Mayram Bībī's fatwa thus stated that, when Bāy Bābā created the waqf, he was no longer in full possession of his mental faculties and was incapable of reasoning and realizing the consequence of his actions and was not in full possession of his mental faculties. ${ }^{139}$ The muftis held that that a testator's disposition of property in such a state was inadmissible (n $\bar{a}-j \bar{a} i z$ wa na $\bar{a}$-mu'tabar) and opined that Bāy Bābā's estate could not constitute a waqf. They suggested in their legal opinion that the shops be divided (qismat namüda) according to the Islamic law of inheritance, given that, "for the legal disposition [of an asset and the rights to it as well as its disposal] to be valid and effective, the reasoning ability of the person who disposes [of the substance and the rights to it] is a [necessary] precondition." 140 The fatwa was summarized in Russian and attached to Mayram Bïbï's appeal. ${ }^{141}$ Once again — as in the case of the first complaint that Șādiq Jān submitted to the authorities and in the report Lykoshin wrote after investigating the charges - the colonial administration was asked to make a decision on the basis of documentation that, although it was written in Russian, embodied notions of justice stemming directly from sharīa.

Bāy Bābā's alleged mental incompetence was a convincing argument. The chancellery of the governor-general accepted it, ignoring the recommendations made by Putintsev, and ruled that new evidence should be collected regarding Bāy Bābā’s death. ${ }^{142}$ It would be wrong to ascribe this decision simply to a zealous bureaucrat's determination to impose the Russian rule of law. Instead, someone in the chancellery must have been persuaded by the argumentation articulated by Mayram Bỉbī on the basis of the fatwa: if, at the moment of the stipulation of the waqf-nāma, Bāy Bābā was on his deathbed, then the endowment deed could be voided. The fact that this line of argument was accepted means that a high-ranking Russian colonial administrator wished to remove Muhyī al-Dīn Khwāja from office.

138 R. Shaham, The Expert Witness in Islamic Courts: Medicine and Crafts in the Service of Law (Chicago: University of Chicago Press, 2010): 135 .

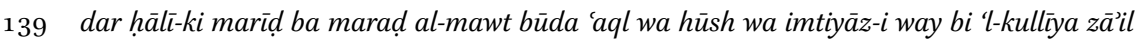
gardìda lā ya'́il wa ma'tūh gardīda bāshad, undated legal opinion (fatwā), TsGARUz, f. I-17, op. 1, d. 4887, 1. 38 .

140 dar tașarrufät-i shar'ìya wa șihhat wa nufüdh-i ān 'aql-i mutașarrif sharț bāshad, ibid.

141 Perevod. Vypiska iz shariatskikh knig, n.d., ibid.: l. 39.

142 Counsellor of the military governor to the city commandant, n.d., ibid.: 1. 16. 
The positive response of the colonial administration to the arguments deployed by Mayram Bībī encouraged Șādiq Jān. The latter, however, realized that, because his previous accusations regarding Muhyī al-Dīn Khwāja's usurpation of the post of mutawalli and squandering the waqf's incomes had been ruled groundless, he needed to find new lines of argument. If, for example, he managed to prove that there were inconsistencies in the waqf-namma, there was a good chance that the waqf would be annulled. It was precisely at this point that Șādiq Jān accused Muhyī al-Dīn Khwāja of having forged the endowment deed (oni utverzhdaiut, chto vakuf vovse ne byl uchrezhden Turambaevym i chto vakuf-name podlozhno). ${ }^{143}$ Presented with this accusation, the provincial chancellery retrieved the original waqf-nāma and had it translated and presented. ${ }^{144}$ It was shown to Muhyī al-Dīn Khwāja and Șādiq Jān for confirmation. When questioned, the qā deed, he had affixed his seal, as had another senior mufti, Mullā 'Abd al-Rasūl. He also pointed out that later, when 'Azīzlār Khān was elected to the post of $q \bar{a} d \bar{l}$, the latter had appointed Dhākir Jān mutawallī of the waqf and had affixed his seal (as had his son, who was also a mufti). ${ }^{145}$

When he was shown the waqf-nāma, Șādiq Jān raised a new argument. He claimed that his uncle had left at his disposal documents attesting to the ownership of the property at hand, that is, the shops. This proved, Șàdiq Jān argued, that Bāy Bābā intended him to take possession of the property; had the latter truly intended to endow the six shops in the waqf deed, he should have attached these documents to the waqf-näma itself, instead. ${ }^{146}$ This new claim, however, was not supported by sharîa: nowhere in Islamic law is it stated that certificates proving the ownership of a given asset have to be attached to a waqf-nāma. In fact, Ṣādiq Jān was unable to obtain a mufti's opinion to support

143 Proshenie, 30.12.1891, ibid.: l. 2. Ṣādiq Jān's new attorney, Anton Glaz, was one of the most renowned Russian lawyers in Tashkent; see above, Introduction.

144 Translation, n.d., ibid.: ll. 52-54.

145 Muhyī al-Dīn Khwāja to the city commandant, 18 Nov. 1892, ibid.: 1. 29.

146 Șādiq Jān to the city commandant, 19 Nov. 1892, ibid.: l. 30. Ṣādiq Jān appealed to the Russian authorities once more and asked again that new probative elements be considered. This time he claimed that Dhākir Jān had never been the mutawallī of the waqf and that Dhākir Jān's father was willing to testify that he had never heard that his son had been appointed to this position. ȘādiqJān also stated that one of the two people named in the waqf deed as a witness - who had given testimony (bayyina) that, in drawing up the deed, Dhākir Jān had acted as a proxy (wakīl) for Bāy Bābā—was unknown to the people of the mahalla. His last argument concerned the seals on the document: according to Șādiq Jān they were affixed to it some years after the waqf-nāma was originally produced. 
this claim, and he could cite no provision in the colonial statutory law that obliged a $q \bar{a} d \bar{\imath}$ to act as he claimed was correct.

Șādiq Jān had tried hard to prove that the waqf-nāma had been altered, in order to divert the income fraudulently from Bāy Bābā's properties. As he had no evidence of this, the provincial chancellery helpfully fabricated some. While preparing documentation for the prosecutor, the officials staffing the provincial chancellery had some leeway to insert explanatory notes (spravka) or reformulate the arguments in petitions. They were therefore in a position to modify key information in favor of or against the $q \bar{a} d \bar{c}$. This is what the Russian officials wrote in their explanatory note:

In the translation of the original [waqf] document [...], there is a note explaining that it is impossible to ascertain precisely the year in which the document was compiled, as it is difficult to decipher the last numbers in the date written on the deed against which a dispute over a [case of] forgery [o podloge] is now under scrutiny. [In addition] we consider that [...] the declaration to the qā donation of the aforementioned property was made on 4 May 1881, as is stated in the document, and was not made by [Bāy Bābā] Turabaev himself, as he was ill, but by an individual named Dhākir Jān, on whom [Bāy Bābā] conferred the powers of attorney, in the presence of two witnesses. The document in question was drawn up on 25 December 1882, one year and seven months after the declaration; there are several seals on the document. ${ }^{147}$

This excerpt from the chancellery's attached explanatory note contains a collection of allegations of the crudest kind. First, the statement that the date of the waqf-namma is impossible to read is absurd. The note made in the margin of the translation, which explains that the date on which the document was drawn up is partially illegible, ${ }^{148}$ does not refer to the Islamic (hijrì ) date, which is an integral part of the waqf-nāma and is clearly 16 Șafar 1299. ${ }^{149}$ It refers, instead, to the date according to the Julian (Old Style)

\footnotetext{
147 Zhurnal obshchego prisutstviia syr-dar'inskogo oblastnogo pravleniia, no. 11, 30.01.1893, TsGARUz, f. I-17, op. 1, d. 32607, l. 62 .

148 [1881] iliv 1882 godu, tak kak tsifry na pole podlinnogo dokumenta tochno opredelit' po neiasnosti takovykh (odin ili dva) nevozmozhno. Perevodchik Aidarov: "[1881] or 1882, the last figure on the document is unclear and impossible to decipher. The translator: Aidarov." Russian translation of the endowment deed, n.d., TsGARUz, f. I-17, op. 1, d. 4887, l. 53.

149 See the endowment deed (waqf-nāma), TsGARUz, f. I-17, op. 1, d. 32607, l. 3 (Fig. 10).
} 
calendar in use in Russia, which the qā righthand margin of the deed to facilitate the filing of the document. Actually, the original waqf-nāma clearly reads jum'a 25 jadī (Friday 25 Capricorn). ${ }^{150}$ It is true that the last figure in the year is slightly smeared [Fig. 10], so that it could be read as either 1881 or 1882 , but this a quibble on the part of the person who added the note, given that the text of the Russian translation of the waqf-nāma stated clearly that the document was notarized on 25 December $1881 .{ }^{151}$

The insertion of the note in the margin of the translation suggesting that the date was difficult to decipher is itself suspicious. While this note was signed by Aidarov, whose signature is also found at the end of the translation, there is no doubt that the translation of the deed in its entirety was the work of another person. Moreover, when Aidarov gave the translation to the provincial chancellery he attached a letter in which he stated that the translation of the waqf-näma was truthful (veren), although he found it doubtful that a qā $\bar{c} \bar{\imath}$ could be delegated the authority to define the stipulations of the waqf. ${ }^{152} \mathrm{Had}$ the date of notarization in fact been impossible to decipher, Aidarov would have mentioned this inconsistency in his letter to the chancellery. Could it be that, after the translation was made, someone in the provincial chancellery asked Aidarov to comb the waqf-näma for inconsistencies? The smear on the last figure of the Julian date was all that the translator managed to find, and he probably offered his remark about the inconsistency of the dates in order to provide the chancellery with evidence to use against Muhyī al-Dīn Khwāja.

The Russians also argued that the endowment had been registered later than it actually was. This was another fabrication, as the entire file contains nothing indicating that the waqf had been dedicated before the notarization of the deed, on 4 May 1881. The Russian administrators were attempting to show that the endowment deed had been notarized later than its actual stipulation. Clearly, if this was the case, it would have meant that the $q \bar{a} d \bar{\imath}$ had exploited Bāy Bābā's illness to craft the certificate as he saw fit, that is, to his own advantage. Once again, it is striking how far the Russian bureaucrats were willing to go in their attempt to undermine the veracity of the endowment deed by introducing arguments based on the Islamic legal principle that dispositions made by a person on his deathbed could be invalidated.

$15^{0}$ Ibid. In Russian Central Asia, scribes often used astrological terms with some latitude in lieu of the Russian terms denoting the months of the Julian calendar; 25 jadī 1881 corresponds to 25 December 1881 .

151 TsGARUz, f. I-17, op. 1, d. 4887, l. 53 .

$15^{2}$ Letter accompanying the translation of the endowment deed, 24.01.1892, ibid.: 1. 51. 


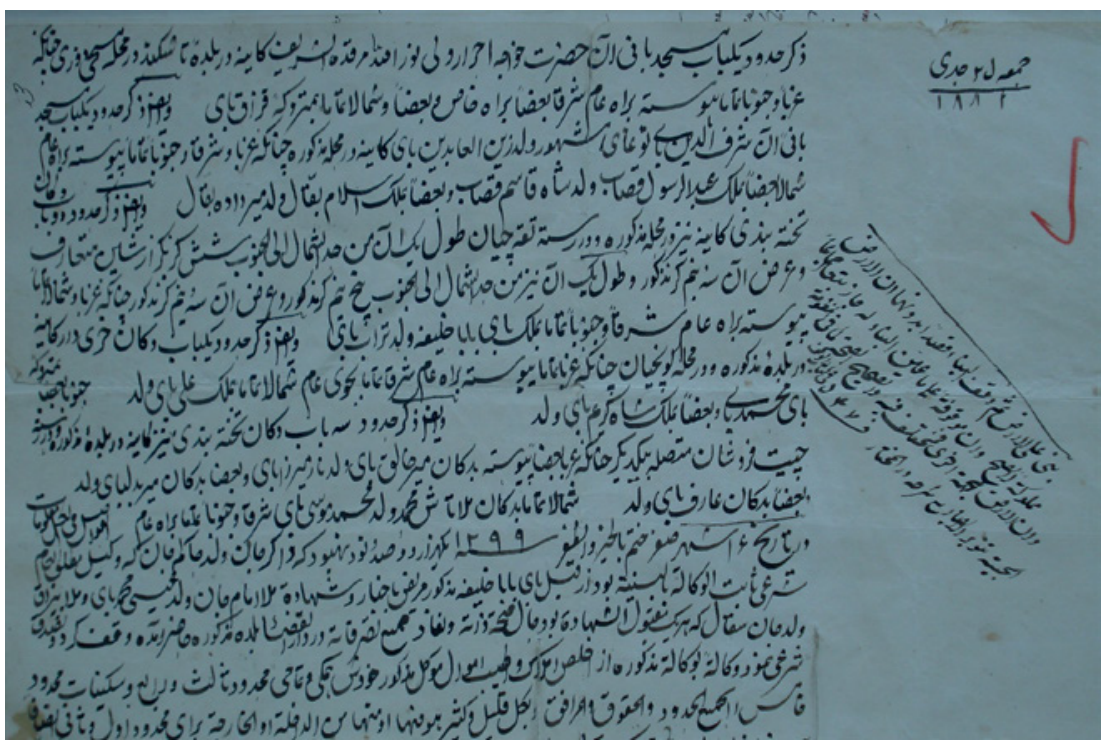

FIGURE 10 Detail of the endowment deed of the two mosques in the Maḥsidüzī mahalla, I. TsGARUz, f. I-17, op. 1, d. 32607 , l. 3 . COURTESY OF THE CENTRAL STATE ARCHIVE OF UZBEKISTAN

Their conspiracy against Muhyī al-Dīn Khwāja led the Russians to make much of the fact that two seals had been added to the deed after it was notarized. The administrators insisted that this was particularly damning evidence of wrongdoing, neglecting to mention that, although two seals had in fact been attached later for a completely different reason, the reason was legitimate and had nothing to do with the crafting of the original document. Muhyī al-Dìn Khwāja explained that, when another person took over his office as qā new judge appointed Dhākir Jān to the post of administrator, recorded this event directly at the end of the deed, and added his seal. ${ }^{153}$ The last line of the waqf-nāma, clearly in a different hand, confirms the statement Muhyī al-Dìn Khwāja made to the colonial officials investigating the case. ${ }^{154}$ In order to ensure that Dhākir Jān's appointment would have shar'i legitimacy, the new $q \bar{a} d \bar{\imath}$ added, "regarding the appointment [to the post of administrator, this right rests with] the aforementioned Bāy Bābā and the person he delegates,

\footnotetext{
153 2-nchīmandīn sūng būlgān qā dị madhkūr waqfgā Dhākir dīgān mutawallì qülgān sababdīn waqf-nāma ākhirīgā bir khațt yā̄ī̄b muhr qülgān īkānlār, ibid.: 1. $290 \mathrm{ob}$.

154 mutawallī naṣb karda shud Dhākir Jān walad-i Ākhūnd Jān rā, TsGARUz, f. I-17, op. 1, d. 32607 , l. 3 .
} 


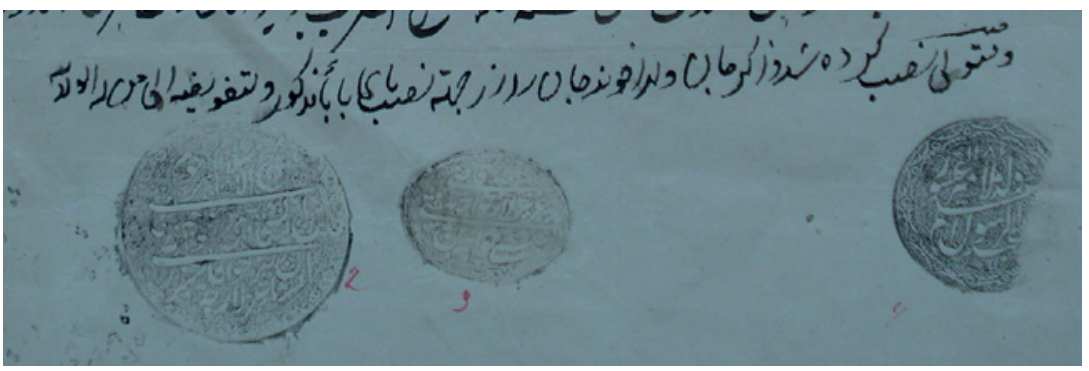

FIGURE 11 Detail of the endowment deed of the two mosques in the Mahsīdūzì mahalla, II. TsGARUz, f. I-17, op. 1, d. 32607, l. 3 .

COURTESY OF THE CENTRAL STATE ARCHIVE OF UZBEKISTAN

who enjoys [legal] authority" (azjihat-i naṣb Bāy Bāba $\bar{a}^{\prime}-i$ madhkūrwa tafwị̣̂ihu ilā man lahu al-wilāya). This formula is a stock phrase used in the original stipulation of the deed, which delegated to the judge the authority to choose the administrator for the waqf (mutawalli-yi madhkūr manșūb bāshad az qibal-i man lahu al-wilāya). 155

This episode proves that the individual who succeeded Muhyī al-Dīn Khwāja in the office of qāọ̄ considered the waqf-nāma and its stipulations fully in accordance with Islamic law. The Russian translation that was given to the colonial authorities confirms this reading and the inferences I have drawn. ${ }^{156}$

Several people in the provincial chancellery evidently wished to concoct false accusations against Muhỵī al-Dīn Khwāja and added misleading notes, inserted undocumented elements, and even manipulated the evidence at hand. However, when the gathered materials and the notes added by the chancellery were sent to the provincial prosecutor for further examination, the prosecutor ruled that the charges against the qā $\bar{\imath}$ were barred by statute and should be dropped. He also ruled that, if they wished, Șādiq Jān and Mayram Bībī could contest Bāy Bābā's will in a sharî́a court. ${ }^{157}$ While, on the one hand, this judgment is striking because it counters Russian statutory law-which gave Central Asians the right to lodge claims with the colonial administration and have cases heard in the imperial courts - on the other hand, the prosecutor's decision probably followed a simple line of argumentation: there was too

155 Ibid.

156 nizhe sego pisano drugim pocherkom nizhesleduiushchee: Zakirdzhan Akhundzhanov mnoiu naznachen mutavalliem na osnovanii togo, chto naznachenie mutavalliia Baibaboiu predostavleno pravo "men'liakhul'viliaia," t.e. kaziiu, TsGARUz, f. I-17, op. 1, d. 4887, l. 54.

157 Register 44, 26.01.1893, ibid., l. 65. 
much Islamic law in the case for his office to handle. It was thus the provincial prosecutor who intervened to clear Muhyì al-Dīn Khwāja of the accusations made against him. In the years that followed, ten other lawsuits for malpractice were filed by the provincial chancellery against the $q \bar{a} d \underline{\imath}$ at the request of other Muslim appellants. In 19o6, thirteen years later, and well after Muhyī al-Dīn Khwāja's death, Ṣādiq Jān tried again to have himself appointed mutawallı̄ of the waqf his uncle had established. ${ }^{158}$

\section{Conclusions}

Appeals by colonial subjects to nonnative administrative authorities are one form of forum shopping that emerged under legal regimes established by imperial powers. By "forum shopping," I refer to the movement of litigants from one legal jurisdiction to another in search of the most favorable ruling. Mitra Sharafi has examined failed attempts to forum-shop among the Parsi community, which spread from colonial Bombay to the princely state of Baroda (in western India), Iran, and Britain and which resemble closely those that occurred in Russian Central Asia. The common feature shared by these two distant colonial polities is, to use Sharafi's words, the existence of "a flow of hopeful litigants". The term Sharafi uses to describe this mechanism is "legal lottery," that is, "a promise that one might win this time, even if one probably would not."159 For the person found guilty, for example, of animal theft, it was tempting to turn to the colonial authorities with an appeal and claim that the judges who ruled against him were corrupt. ${ }^{160}$ As we stated previously, the procedure cost little and was usually slow, and it might well happen that, while investigating, Russian authorities would find other irregularities on the basis of which to charge a native judge with malpractice.

The term "legal lottery" emphasizes the ephemeral character of many of the cases that colonial subjects asked the authorities to hear. This applies also to Central Asia, where the large majority of the complaints filed with the Russian officers consisted of false accusations that did not yield the hopedfor results. Thus, the appeals of colonial subjects may look like "acts of micro-

$15^{8}$ Proshenie of Șādiq Jān to the governor-general, 10.02.1907, TsGARUz, f. I-36, op. 1, d. 4364, l. 3 .

159 M. Sharafi, "The Marital Patchwork of Colonial South Asia: Forum Shopping from Britain to Baroda." LHR 28/4 (2010): 1009.

160 TsGARUz, f. I-21, op. 1, d. 144, ll. 1-26. 
scopic agency,"161 the more so, if one evaluates them against the backdrop of the financial and emotional investments they required.

There are, however, other important aspects of the phenomenon that the concept of the legal lottery overshadows and obscures. By focusing instead, as we have done, on the relationship between local appellants and imperial authorities, we are able to shed light on the process by which the colonial legal culture was constituted through social relations. The district and provincial chancelleries of the Russian colonial administration in Central Asia were venues where the local population engaged the state in a dialogue over legal questions. It is within this institutional framework, outside the courtroom, that Russian bureaucrats and Central Asian Muslims had the scope to elaborate their notions of "lawful" and "unlawful."

Colonial subjects engaged in active discussions about the interpretation of procedural laws. On occasion, they turned to professionals and sought consultation, as in the case examined here, but their "jurisdictional jockeying"162 did not depend exclusively on the colonial lawyers or local intermediaries who wrote their petitions. It appears that the boundaries between colonial state and local society were so indistinct as to allow the indigenous population to adopt the appropriate moral vocabulary, the discretionary powers of shari $a$ courts being a case in point. This happened routinely, as Central Asians filed appeal after appeal, gaining experience each time and honing their skills at dealing with colonial administrators.

The relationship between colonial state law and Muslim society was mutually constitutive: Muslims' knowledge of legal matters was significantly influenced by their dialogue with colonial officials, while Muslims' conceptions of justice structured the practices of the Russian bureaucrats who heard their appeals. By formulating their arguments in various ways, colonial subjects could determine how their appeals were handled at the various levels of the state administration. They could also influence the decision-making process of Russian officials and could ultimately shape the notions of justice and injustice according to which a particular issue was examined.

Ṣādiq Jān and Mayram Bībī laid their claims against Muhyī al-Dīn Khwāja precisely because Russian statutory law allowed them to take their grievances to the administrative authorities. The appeals and the bureaucratic paperwork produced by Russian officials represent normative practices

161 Sharafi, "The Marital Patchwork of Colonial South Asia: Forum Shopping from Britain to Baroda": 981.

162 The terminology here is Benton's: Law and Colonial Cultures: Legal Regimes in World History: 1400-1900 (Cambridge: Cambridge University Press, 2002): 3, 13, 29. 
reinforcing colonial rule and its cultural project. ${ }^{163}$ As they addressed their appeals to the administrative authority of the colony, Șādiq Jān and Mayram Bībī may, in a sense, have conferred legitimacy upon the legal authority of the colonial state. In addition, they took legal action against an Islamic institution—a qā malpractice would be reviewed by the provincial prosecutor according to the general laws of the empire. But, by exploiting the appellate system and entwining Russian bureaucrats in their own machinations against a Muslim judge, Ṣādiq Jān and Mayram Bībī managed to draw colonial administrative authorities into the orbit of Islamic law. As Ṣādiq Jān and Mayram Bībī successfully exercised their normative agency, Russian officials made great show of referring to Islamic procedural laws in their judicial review. Such practices of legal hybridization were not among the prerogatives of the Russian administrative authorities, a fact that the provincial prosecutor immediately reinforced by redirecting the case to the jurisdiction of a sharita court.

These unfounded accusations of judicial malfeasance and corruption did undermine $q \bar{a} d \bar{l} \bar{s}^{\prime}$ legal authority, but only partly. As above, under the institutional arrangements introduced by Russians, qā dīs enjoyed unprecedented power because they could count on Russian police forces for the enforcement of their judgments. In addition, after the fall of the Muslim potentates in the areas that formerly belonged to the Khoqand khanate and the Bukhara emirate, qā did not have to compete for legal authority with governors and representatives of the royal court.

163 Ibid.: 148-9; Sharafi, "The Marital Patchwork of Colonial South Asia": 980-1, 1009. 